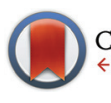

CrossMark

Cite this: Dalton Trans., 2016, 45 19072

Received 6th September 2016, Accepted 29th October 2016

DOI: $10.1039 / c 6 d t 03477 b$

www.rsc.org/dalton

\section{Monomeric Ti(Iv)-based complexes incorporating luminescent nitrogen ligands: synthesis, structural characterization, emission spectroscopy and cytotoxic activities $\uparrow$}

\author{
Georges Khalil, ${ }^{a}$ Christophe Orvain,,${ }^{\mathrm{b}, \mathrm{c}}$ Lu Fang, ${ }^{a}$ Laurent Barloy, ${ }^{a}$ Alain Chaumont, \\ Christian Gaiddon, ${ }^{\mathrm{b}, \mathrm{c}}$ Marc Henry, ${ }^{a}$ Nathalie Kyritsakas ${ }^{\mathrm{d}}$ and Pierre Mobian ${ }^{a}$
}

\begin{abstract}
This manuscript describes the synthesis of a series of neutral titanium(iv) monomeric complexes constructed around a $\mathrm{TiO}_{4} \mathrm{~N}_{2}$ core. The two nitrogen atoms that compose the coordination sphere of the metallic center belong to 2,2'-bipyrimidine ligands homo-disubstituted in the 4 and 4' positions by methyl (2a), phenylvinyl (2b), naphthylvinyl (2c) or anthrylvinyl (2d) groups. The crystal structures of these complexes named $\left[\mathrm{Ti}(\mathbf{1})_{2}(\mathbf{2} \mathbf{a})\right],\left[\mathrm{Ti}(\mathbf{1})_{2}(\mathbf{2} \mathbf{b})\right],\left[\mathrm{Ti}(\mathbf{1})_{2}(\mathbf{2} \mathbf{c})\right]$ and $\left[\mathrm{Ti}(\mathbf{1})_{2}(\mathbf{2} \mathbf{d})\right]$ (where $\mathbf{1}$ is a $2,2^{\prime}$-biphenolato ligand substituted in the 6 and 6 ' positions by phenyl groups) are reported. The hydrolytic stability of the four complexes is evaluated by monitoring the evolution of the free $\mathbf{2 a}-\mathbf{d}$ signals by ${ }^{1} \mathrm{H}$ NMR spectroscopy. For the conditions tested $\left(6 \mathrm{mM}, \mathrm{DMSO}-d_{6} / \mathrm{D}_{2} \mathrm{O}: 8 / 1\right)$, a rather good stability with $t_{1 / 2}$ ranging from 180 to $300 \mathrm{~min}$ is determined for the complexes. In the presence of an acid (DCl), the hydrolysis of $\left[\mathrm{Ti}(\mathbf{1})_{2}(\mathbf{2 a})\right]$ is faster than without an acid. The cytotoxic activity against gastric cancer cells of the titanium-based compounds and the free disubstituted 2,2'-bipyrimidine ligands is tested, showing $I C_{50}$ ranging from $6.2 \pm$ $1.2 \mu \mathrm{M}$ to $274 \pm 56 \mu \mathrm{M}$. The fluorescence studies of the ligands $\mathbf{2 a}-\mathbf{d}$, and the complexes $\left[\mathrm{Ti}(\mathbf{1})_{2}(\mathbf{2 a}-\mathbf{d})\right]$ reveal an important fluorescence loss of the ligands $\mathbf{2} \mathbf{c}$ and $\mathbf{2} \mathbf{d}$ upon coordination with the Ti(1) $)_{2}$ fragment. Frontier orbitals obtained by DFT calculations permit us to explain this fluorescence quenching.
\end{abstract}

\section{Introduction}

Luminescence is a recurrent property displayed by transition metal complexes. ${ }^{1}$ Luminescent transition metal complexes are particularly attractive for applications as chemosensors, ${ }^{2}$ probes for biological molecules ${ }^{3}$ or organic light emitting diodes. ${ }^{4}$ Luminescent transition metal complexes such as zinc, ${ }^{5}$ copper, ${ }^{6}$ gold, ${ }^{7}$ platinum ${ }^{8}$ or $\mathrm{d}^{6}$ transition metal com-

\footnotetext{
${ }^{a}$ Laboratoire de Chimie Moléculaire de l'Etat Solide, UMR 7140 UDS-CNRS, Université de Strasbourg, 4 rue Blaise Pascal, F-67000 Strasbourg, France. E-mail: mobian@unistra.fr

${ }^{b}$ Laboratoire des "Mécanismes moléculaires de la réponse au stress et pathologies", Inserm U1113 3 avenue Molière, 67200 Strasbourg, France

${ }^{c}$ Département Cancer, Fédération de Médecine Translationnelle de Strasbourg, Université de Strasbourg, 67200 Strasbourg, France

${ }^{d}$ Laboratoire de Tectonique Moléculaire, UMR 7140 UDS-CNRS,

Université de Strasbourg, 4 rue Blaise Pascal, F-67000 Strasbourg, France

$\dagger$ Electronic supplementary information (ESI) available: Supplementary figures and data, including photoluminescence data (spectra and lifetimes), and DFT calculations concerning the $\left[\mathrm{Ti}(\mathbf{1})_{2}(2 \mathrm{c})\right]$ complex (PDF), X-ray crystal structure details (CIF). CCDC 1468167-1468169 and 1468801. For ESI and crystallographic data in CIF or other electronic format see DOI: 10.1039/c6dt03477b
}

plexes (especially ruthenium) ${ }^{9}$ have also been extensively applied for fluorescence cell imaging.

Titanium(Iv) complexes are very diverse and represent a major class of compounds widely used in many fields of modern molecular science. Organometallic and coordination titanium(Iv) compounds are powerful reagents for catalytic enantioselective processes,${ }^{10}$ organic transformations ${ }^{11}$ and as initiators for polymerization reactions. ${ }^{12}$ Alkoxides or aryloxides titanium species are precursors to generate titaniumbased materials through sol-gel processes. ${ }^{13}$ In metallo-supramolecular chemistry, titanium(Iv) centers are intensively employed to create self-assembled architectures from oxygen ligands ${ }^{14}$ or from multiple components. ${ }^{15}$ Applications of titanium(Iv) complexes in bioinorganic chemistry are also deeply investigated, as long as titanium(Iv) is recognized for its low toxicity for living matter. Therefore, titanium is found in many biomaterials and numerous applications of Ti(Iv) in a medical or biological context have been described. ${ }^{16,17}$ Particularly, titanium(Iv) complexes are promising candidates for developing new anti-cancer drugs with minor side effects. ${ }^{18,19}$

As we were intrigued by the rarity of reports detailing the coordination chemistry of titanium(Iv) complexes bearing 
luminescent ligands, ${ }^{20}$ this work aimed to study the ligating properties to a titanium(Iv) center of fluorescent ligands and their resulting emissions. Thus, we report the synthesis and the structural characterization of a series of $\mathrm{TiO}_{4} \mathrm{~N}_{2}$-based monomeric octahedral complexes bearing various substituted 2,2'-bipyrimidines (Chart 1). These complexes are built from two biphenolato derivatives and one substituted 2,2'-bipyrimidine unit as depicted in Fig. 1. The choice of these nitrogen ligands is motivated by the fact that $2,2^{\prime}$-bipyrimidine has shown to be a well-adapted chelate to successfully generate $\mathrm{TiO}_{4} \mathrm{~N}_{2}$-based complexes. ${ }^{15,21}$ Also, 4,4'-dimethyl-2,2'-bipyrimidine can be easily functionalized by various groups through Knoevenagel reactions. ${ }^{22}$ Therefore, the synthesis of a $\mathrm{TiO}_{4} \mathrm{~N}_{2}-$ based monomeric octahedral complex bearing $2,2^{\prime}$-bipyrimidines substituted by "classical" fused polycyclic aromatic emitters, as the naphthyl or anthryl group, ${ }^{23}$ was envisaged. Additionally, we also detail in this manuscript some biological applications of these Ti(Iv)-based species.
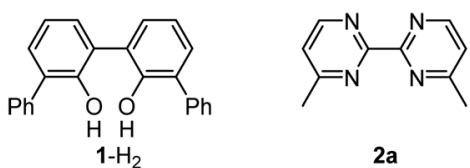

$2 a$

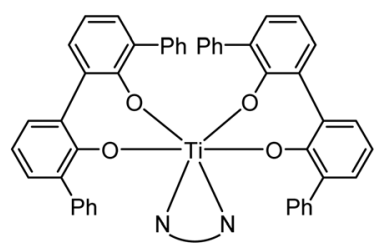

$\left[\mathrm{Ti}(1)_{2}(2 \mathrm{a}-\mathrm{d})\right]$

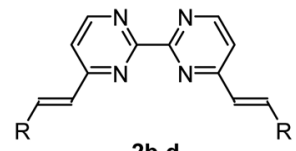

2b-d

b : $\mathrm{R}=\mathrm{Ph}$

c : $R=2$-naphthyl

d : $R=9$-anthryl
Chart 1

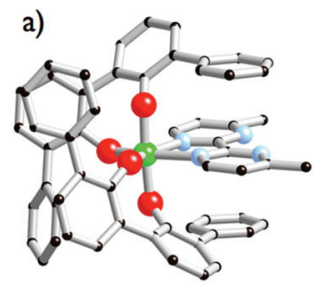

c)

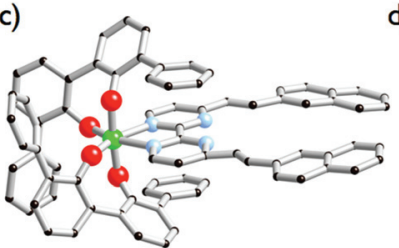

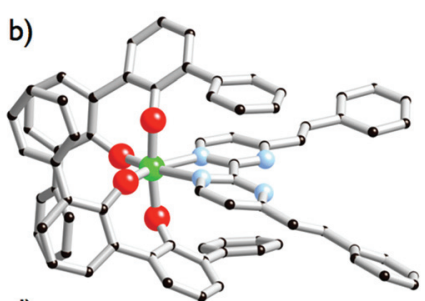

d)

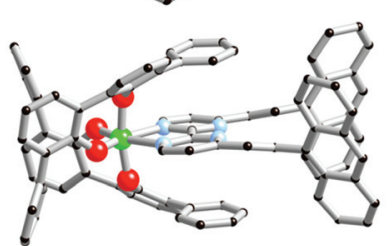

Fig. 1 Solid-state molecular structures of $\left[\mathrm{Ti}_{(1}\left(\mathbf{1}_{2}(\mathbf{2 a})\right](\mathrm{a}),\left[\mathrm{Ti}(\mathbf{1})_{2}(\mathbf{2 b})\right]\right.$ (b), $\left[\mathrm{Ti}\left(\mathbf{1}_{2}(\mathbf{2 c})\right]\right.$ (c) and [Ti(1) 2 (2d)] (d). Ti atoms are in green, $\mathrm{C}$ atoms in black, $\mathrm{O}$ atoms in red, $\mathrm{N}$ atoms in blue. Hydrogen atoms are omitted for clarity.

\section{Results and discussion}

\section{Synthesis of ligands and complexes}

The ligands $\mathbf{2 b}-\mathbf{d}$ were synthesized according to Scheme 1 in a one-step double Knoevenagel condensation starting from the 4,4'-dimethyl-2,2'-bipyrimidine precursor $2 \mathrm{a}^{22}$ Compound $2 \mathrm{a}$ was condensed with benzaldehyde, 2-naphthaldehyde or 9-anthraldehyde using ${ }^{t} \mathrm{BuOK}$ to afford the targeted bipyr-

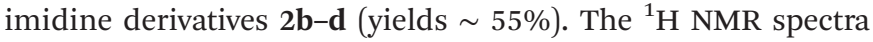
for $\mathbf{2 b - d}$ highlighted doublets with trans vinylic coupling $\left({ }^{3} \mathrm{~J} \sim 16 \mathrm{~Hz}\right)$ confirming the formation of the desired bipyrimidine compounds. Having in hand this set of bipyrimidine derivatives, the synthesis of the targeted octahedral monomeric complexes $\left[\mathrm{Ti}(\mathbf{1})_{2}(\mathbf{2 a}-\mathbf{d})\right]$ constructed around a $\mathrm{TiO}_{4} \mathrm{~N}_{2}$ core was undertaken. The complexes were obtained by following a well-established procedure ${ }^{21}$ based on the exchange of the labile monodentate ligands coordinating the metal center in $\left[\mathrm{Ti}(\mathbf{1})_{2}\left(\mathrm{HO}^{\mathrm{i}} \mathrm{Pr}\right)_{2}\right]^{24}$ by a nitrogen bidentate ligand as proposed in eqn (1).

$$
\left[\operatorname{Ti}(\mathbf{1})_{2}\left(\mathrm{HO}^{\mathrm{i}} \mathrm{Pr}\right)_{2}\right]+\mathbf{2 a}-\mathbf{d} \rightarrow\left[\mathrm{Ti}(\mathbf{1})_{2}(\mathbf{2} \mathbf{a}-\mathbf{d})\right]+2 \mathrm{HO}^{\mathrm{i}} \mathrm{Pr}
$$

Complexes $\left[\mathrm{Ti}(\mathbf{1})_{2}(\mathbf{2 a}-\mathbf{d})\right]$ were isolated as single crystals suitable for X-ray analysis by dissolving in a chlorinated solvent the $\left[\mathrm{Ti}(\mathbf{1})_{2}\left(\mathrm{HO}^{\mathrm{i}} \mathrm{Pr}\right)_{2}\right]$ precursor with one equivalent of the 2a-d ligand after slow vapour diffusion of $n$-pentane. The molecular structures of complexes $\left[\operatorname{Ti}(\mathbf{1})_{2}(\mathbf{2 a}-\mathbf{d})\right]$ are shown in Fig. 1. As expected, the structures highlight monomeric $\mathrm{C}_{2}$-symmetric complexes incorporating an octahedral $\mathrm{TiO}_{4} \mathrm{~N}_{2}$ unit. Interestingly, these complexes crystallize in achiral space groups with the exception of $\left[\operatorname{Ti}(\mathbf{1})_{2}(\mathbf{2 a})\right]$. [ $\left.\operatorname{Ti}(\mathbf{1})_{2}(\mathbf{2 a})\right]$ crystallizes in the noncentrosymmetric $P 2_{1} 2_{1} 2_{1}$ space group when the formation of the complex is performed in 1,2-dichloroethane and $n$-pentane is used as a precipitant. The $\Lambda$-[Ti(1) $\left.)_{2}(\mathbf{2 a})\right]$ enantiomer is observed in the analyzed crystal. The Flack parameter of $0.006(15)$ determined for the $\Lambda$-[Ti(1) $\left.)_{2}(\mathbf{2 a})\right]$ structure resolution confirms the absolute configuration attribution. Concerning the molecular structures description, it is worth noticing that the aromatic units substituting the bipyrimidine ligands in $\left[\operatorname{Ti}(\mathbf{1})_{2}(\mathbf{2 b})\right]$ and $\left[\operatorname{Ti}(\mathbf{1})_{2}(\mathbf{2 c})\right]$ are coplanar to the neighbouring pyrimidine ring. The situation is different for $\left[\mathrm{Ti}(\mathbf{1})_{2}(\mathbf{2 d})\right]$ since the two anthryl groups adopt an almost orthogonal arrangement with respect to the pyrimidine rings. In all structures, the double bonds adopt a trans isomerism as indicated by the ${ }^{1} \mathrm{H}$ NMR analysis of the free ligands. The metrical description of the structures is unexceptional. The Ti-O $(d(\mathrm{Ti}-\mathrm{O})=1.86 \pm$ $0.06 \AA)$ and $\mathrm{Ti}-\mathrm{N}(d(\mathrm{Ti}-\mathrm{N})=2.238 \pm 0.004 \AA)$ bond distances measured in these complexes are rather similar and identical,

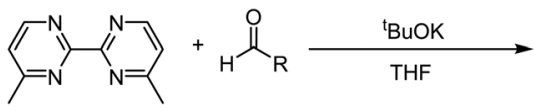

$2 a$

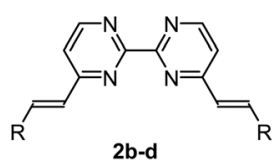

$2 b-c$
Scheme 1 General synthetic scheme followed to generate compounds 2b-d. 
respectively. The coordination polyhedra found in these structures are distorted as attested by the mean angles measured around the titanium atoms $\left(\mathrm{N}-\mathrm{Ti}-\mathrm{N}=71.4^{\circ} \pm 1.2\right.$, $\left.\mathrm{O}-\mathrm{Ti}-\mathrm{O}_{(\mathrm{O} \text { trans to } \mathrm{N})}=111.3^{\circ} \pm 1.6\right)$. We also notice in $\left[\mathrm{Ti}(\mathbf{1})_{2}(\mathbf{2 d})\right]$ that the two anthryl groups are rather distant from one another, as the closest $\mathrm{C}-\mathrm{C}$ distance measured between the two anthryl units is found to be $d\left(\mathrm{C}_{\text {anthryl }}{ }^{-} \mathrm{C}_{\text {anthryl }}\right)=6.66 \AA$.

\section{Hydrolytic stability}

Owing to the poor or moderate hydrolytic stability usually observed for molecular Ti(Iv) species such as classical anticancer titanium-based compounds like budotitane and titanocene dichloride, ${ }^{25 a-c}$ the behaviour of compounds [Ti(1) $\left.)_{2}(\mathbf{2 a - d})\right]$ towards hydrolysis has been evaluated by following a methodology similar to the one already reported for titanium complexes. ${ }^{25 d-f}$ These studies were conducted by ${ }^{1} \mathrm{H}$ NMR analysis of solutions in DMSO- $d_{6}$ of the $\left[\mathrm{Ti}(\mathbf{1})_{2}(\mathbf{2 a}-\mathbf{d})\right]$ complexes over time, upon addition of $\mathrm{D}_{2} \mathrm{O}$ at room temperature. For these analyses, a large amount of $\mathrm{D}_{2} \mathrm{O}(1000$ equivalents versus the complex) was added to the complex solution so that a final complex solution concentration of $6 \mathrm{mM}$ was obtained. It should be noted first that when the concentration of the complex solutions was doubled, an orange precipitate formed instantaneously, reflecting the moderate solubility of these species in polar media. Secondly, when the same experiment was performed without $\mathrm{D}_{2} \mathrm{O}$, a slight degradation of the initial complex was noticed in DMSO. Next, the resulting $6 \mathrm{mM}$ samples were analyzed by ${ }^{1} \mathrm{H}$ NMR. The evolution of the mixtures composition was monitored for $\left[\operatorname{Ti}(\mathbf{1})_{2}(\mathbf{2 a})\right]$, $\left[\operatorname{Ti}(\mathbf{1})_{2}(\mathbf{2} \mathbf{b})\right]$ and $\left[\operatorname{Ti}(\mathbf{1})_{2}(\mathbf{2 c})\right]$ by integrating the bipyrimidine $6,6^{\prime}$ proton resonances for the complex and for the free diimine ligand. For compound $\left[\operatorname{Ti}(\mathbf{1})_{2}(\mathbf{2 d})\right]$, the situation was different, as the vinylic proton signals were monitored. The integration plots of these signals overtime for complexes $\left[\operatorname{Ti}(\mathbf{1})_{2}(\mathbf{2 a}-\mathbf{d})\right]$ are shown in Fig. 2. The complete transformation of the complexes over a period of time of more than 16 hours is not observed. By analyzing the mixtures after one week of their preparation, the presence of a not negligible amount of the starting complexes is still noticed. Also, the absence of free 2,2'-biphenol derivative in solution is confirmed. Therefore, the formation of titanium(rv) oxo-aggregates incorporating 1 through an olation or oxolation reaction mechanism could be envisaged since oxo-clusters are common products when low nuclearity titanium(rv) complexes react with water. ${ }^{26}$ The presence of novel species formed upon hydrolysis in solution is confirmed by NMR analysis. The aromatic region of the ${ }^{1} \mathrm{H}$ NMR spectrum indicates broad signals different from the ${ }^{1} \mathrm{H}$ NMR signature of $1-\mathrm{H}_{2}$. ES-MS analysis of an aliquot also proves the formation of unknown hydrolytic products displaying molecular weights not compatible with the initial complex and the free ligands (see the ESI†). Plotting $\ln [$ complex] or $1 /[$ complex] with respect to time indicated highly complex kinetics for these hydrolytic processes. The $t_{1 / 2}$ values found for these experiments demonstrated significant differences between each reaction (Table 1). Complex $\left[\operatorname{Ti}(\mathbf{1})_{2}(\mathbf{2 a})\right]$ exhibits a faster hydrolysis rate compared to $\left[\operatorname{Ti}(\mathbf{1})_{2}(\mathbf{2 b})\right],\left[\operatorname{Ti}(\mathbf{1})_{2}(\mathbf{2} \mathbf{c})\right]$ or $\left[\operatorname{Ti}(\mathbf{1})_{2}(\mathbf{2 d})\right]$.

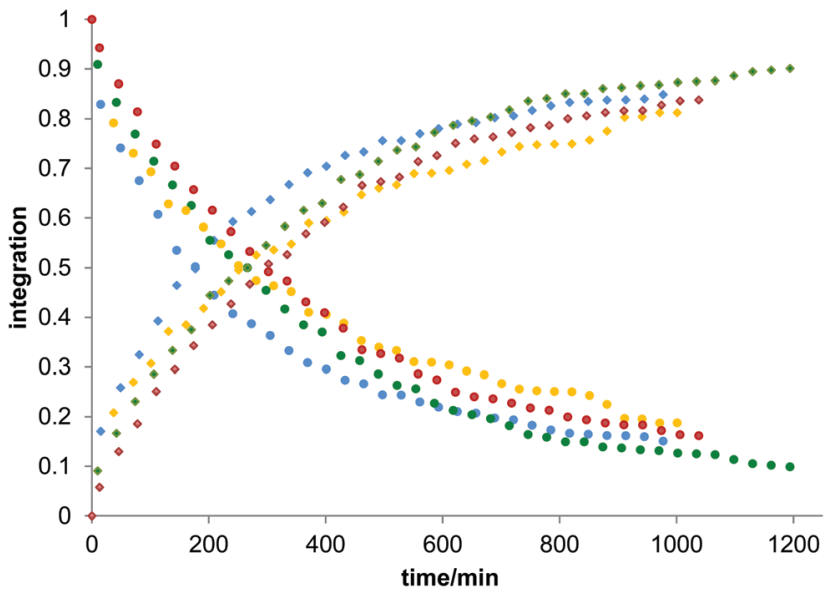

Fig. 2 Plots of the integration of the bipyrimidine 6,6' proton signals related to the bound diimine ligands and the free ligands for complexes $\left[\mathrm{Ti}(1)_{2}(2 \mathrm{a})\right],\left[\mathrm{Ti}(1)_{2}(2 \mathrm{~b})\right]$ and $\left[\mathrm{Ti}(1)_{2}(2 \mathrm{c})\right]$. For compound $\left[\mathrm{Ti}(1)_{2}(2 \mathrm{~d})\right]$, the vinylic proton signals were monitored. In these experiments, $\mathrm{D}_{2} \mathrm{O}(50 \mu \mathrm{l})$ was added to the solution of the complex in DMSO- $d_{6}$ to give a final complex concentration of $6 \mathrm{mM}$. The blue, yellow, green and red dots correspond to the measurements made for $\left[T i(1)_{2}(2 a)\right]$, [Ti(1) $\left.)_{2}(2 b)\right]$, $\left[\mathrm{Ti}(1)_{2}(2 \mathrm{c})\right]$ and $\left[\mathrm{Ti}(1)_{2}(2 \mathrm{~d})\right]$, respectively. Dots are the integrations corresponding to the coordinated diimine ligands, squares are the integrations of the free bipyrimidine ligands. The $t_{1 / 2}$ values of hydrolysis calculated from these plots are compiled in Table 1.

Table $1 t_{1 / 2}$ Values determined for the hydrolytic processes. Ligand volumes computed from the crystal structures $\left[\mathrm{Ti}(1)_{2}(2 \mathrm{a}-\mathrm{d})\right]$

\begin{tabular}{lll}
\hline & $t_{1 / 2}(\min )( \pm 5 \%)$ & $\begin{array}{l}\text { Volume of ligands } \\
\text { 2a-d }\left(\AA^{3}\right)( \pm 10 \%)\end{array}$ \\
\hline$\left[\operatorname{Ti}(\mathbf{1})_{2}(\mathbf{2 a})\right]$ & 180 & 163 \\
{$\left[\operatorname{Ti}(\mathbf{1})_{2}(\mathbf{2 b})\right]$} & 250 & 320 \\
{$\left[\operatorname{Ti}(\mathbf{1})_{2}(\mathbf{2 c})\right]$} & 270 & 406 \\
{$\left[\operatorname{Ti}(\mathbf{1})_{2}(\mathbf{2 d})\right]$} & 300 & 498
\end{tabular}

A linear relationship was found between these $t_{1 / 2}$ values and the volumes of the bipyrimidine ligands were computed from the crystal structures of $\left[\operatorname{Ti}(\mathbf{1})_{2}(\mathbf{2 a}-\mathbf{d})\right]$ with the PACHA software $^{27,28}$ as shown in Fig. 3. This relationship reveals the shield effect played by the aromatic groups substituting the

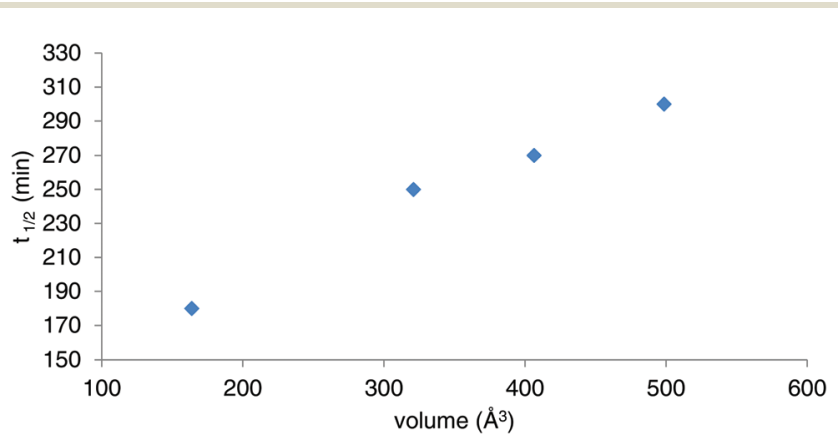

Fig. 3 Plot of the $t_{1 / 2}$ values determined for $\left[T i(1)_{2}(2 a-d)\right]$ in the course of the hydrolytic stability studies vs. the molecular volumes of $2 a-d$ calculated from the $\left[T i(1)_{2}(2 a-d)\right]$ crystal structures. 


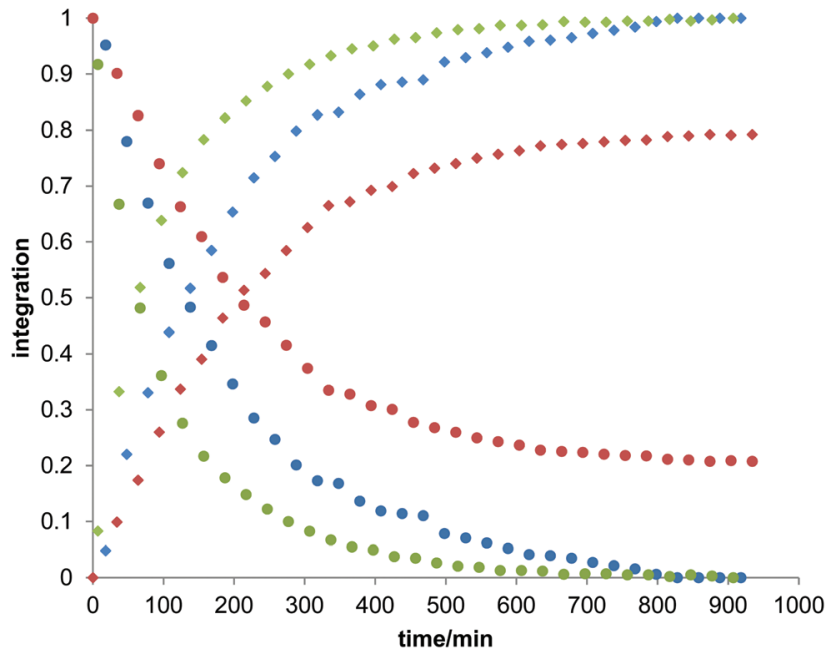

Fig. 4 Plots of the integration of the bipyrimidine 6,6' proton signals related to the bound diimine ligands (dots) and the free ligands (squares) in the spectra of $\left[\mathrm{Ti}(1)_{2}(2 \mathrm{a})\right]$. The red curves correspond to the measurement made for a solution of $\left[\mathrm{Ti}(1)_{2}(2 \mathrm{a})\right]$ in DMSO- $\mathrm{d}_{6}(450 \mu \mathrm{l})$ where $\mathrm{D}_{2} \mathrm{O}$ $(50 \mu \mathrm{l})$ was added. The green and blue curves correspond to the measurements made for a solution of $\left[\mathrm{Ti}(1)_{2}(2 \mathrm{a})\right]$ in DMSO- $\mathrm{d}_{6}(450 \mu \mathrm{l})$ where $\mathrm{D}_{2} \mathrm{O}$ and $\mathrm{DCl}$ were added $\left(50 \mu \mathrm{l}\right.$ in total for the volume of $\mathrm{D}_{2} \mathrm{O}$ and $\mathrm{DCl}$ ). The green curves correspond to the experiment conducted with $2.5 \mu \mathrm{l}$ of $\mathrm{DCl}$ solution (38 wt\% in $\mathrm{D}_{2} \mathrm{O}$ ) whereas the blue curves correspond to the experiment conducted with $0.5 \mu \mathrm{l}$ of $\mathrm{DCl}$ solution (38 wt $\%$ in $D_{2} O$ ). $t_{1 / 2}=67 \mathrm{~min} \pm 5 \%$ for the experiment conducted with $2.5 \mu \mathrm{l}$ of $\mathrm{DCl} ; t_{1 / 2}=138 \mathrm{~min} \pm 5 \%$ for the experiment conducted with $0.5 \mu \mathrm{l}$ of $\mathrm{DCl}$.

bipyrimidine ligands against water. Next, the role played by an acid on the complex $\left[\operatorname{Ti}(\mathbf{1})_{2}(\mathbf{2 a})\right]$ stability was examined by repeating the hydrolysis experiment in the presence of $\mathrm{DCl}$ (38 wt\% in $\mathrm{D}_{2} \mathrm{O}$ ). It appears that with $\mathrm{DCl}$, the transformation of the starting $\left[\operatorname{Ti}(\mathbf{1})_{2}(\mathbf{2 a})\right]$ complex is nearly quantitative after 10 hours for the two DCl concentrations tested as shown in Fig. 4. With an excess of DCl (9 equivalents versus $\left[\operatorname{Ti}(\mathbf{1})_{2}(\mathbf{2 a})\right]$ ), the $t_{1 / 2}$ value of the complex is divided by two in comparison to an experiment conducted with 1.8 equivalent of DCl $v s$. $\left[\operatorname{Ti}(\mathbf{1})_{2}(\mathbf{2 a})\right]$. Altogether, with an acid, the disappearance of the complex is faster than the same reaction performed without DCl.

\section{Photophysical analyses}

To the best of our knowledge, there are very few reports of titanium(Iv) coordination complexes that would be photoluminescent in solution at room temperature, if we exclude titanium phthalocyanines, which are very specific species. ${ }^{29}$ Yet some other group 4 metal complexes (Zr, Hf) exhibit such properties. $^{30}$ However, the luminescence of several Ti complexes at $77 \mathrm{~K}$ has been investigated. ${ }^{31}$ Besides, substituted pyrimidines are a class of organic molecules, which often display light-emitting properties in solution at ambient temperature, and which have even been considered as candidates for OLEDs. ${ }^{32}$ Unsubstituted 2,2'-bipyrimidine has been used as a bridging ligand in photoluminescent binuclear lanthanide complexes. ${ }^{33}$ Moreover, various substituted 2,2'-bipyr- imidines and their coordination complexes have been reported in the literature, which display interesting photophysical properties (fluorescence and non-linear optics). ${ }^{34}$

In the present section, we describe the optical properties, viz. absorption and emission spectroscopy, of solutions in dichloromethane of the ligands $\mathbf{1}-\mathrm{H}_{2}$ and $\mathbf{2 a - d}$, and of the derived titanium complexes $\left[\operatorname{Ti}(\mathbf{1})_{2}(\mathbf{2 a}-\mathbf{d})\right]$. The data obtained in solution at room temperature are presented in Fig. 5 and 6 and summarized in Table 2. Incidentally, the UV-vis spectrum of $1-\mathrm{H}_{2}$ has been reported in the literature, but in a different solvent. $^{35}$

Overall, the compounds absorb UV-vis light over the 240-500 nm range. The $\lambda_{\max }$ value of compound $2 \mathbf{a}$ in $\mathrm{CH}_{2} \mathrm{Cl}_{2}$ $(244 \mathrm{~nm})$ is close to the value reported in EtOH $(248 \mathrm{~nm}){ }^{36}$ A significant bathochromic shift is observed for the phenylvinylsubstituted bipyrimidine $\mathbf{2 b}$, in agreement with an extended

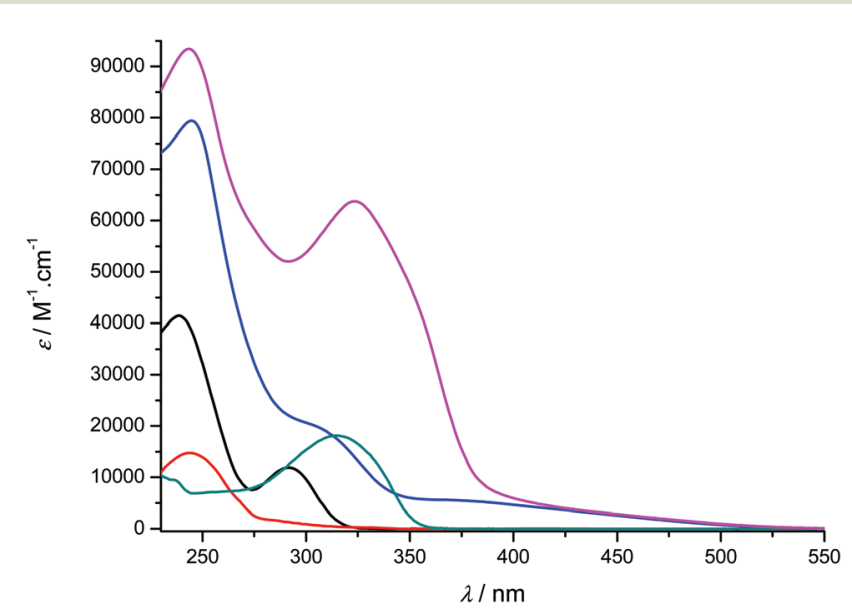

Fig. 5 UV-visible absorption spectra of compounds $1-\mathrm{H}_{2}$ (black), $2 \mathrm{a}$ (red), $\left[\mathrm{Ti}(1)_{2}(2 \mathrm{a})\right]$ (blue), 2b (green) and $\left[\mathrm{Ti}(1)_{2}(2 \mathrm{~b})\right]$ (pink) recorded at room temperature in $\mathrm{CH}_{2} \mathrm{Cl}_{2}$ (concentration range: 9-55 $\mu \mathrm{M}$ ).

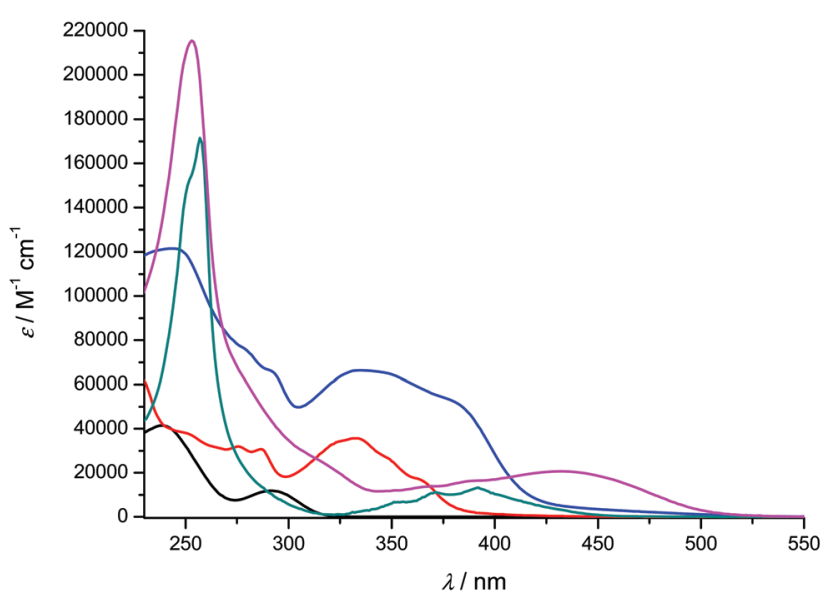

Fig. 6 UV-visible absorption spectra of compounds 1- $\mathrm{H}_{2}$ (black), 2c (red), $\left[\mathrm{Ti}(1)_{2}(2 \mathrm{c})\right]$ (blue), $2 \mathrm{~d}$ (green) and $\left[\mathrm{Ti}(1)_{2}(2 \mathrm{~d})\right]$ (pink) recorded at room temperature in $\mathrm{CH}_{2} \mathrm{Cl}_{2}$ (concentration range: 2-18 $\mu \mathrm{M}$ ). 
Table 2 Photophysical data of the ligands and titanium complexes ${ }^{a}$

\begin{tabular}{|c|c|c|c|}
\hline Compound & $\frac{\text { Absorption }}{\lambda_{\max } / \mathrm{nm}(\log \varepsilon)^{b}}$ & \multicolumn{2}{|c|}{ Photoluminescence } \\
\hline $1-\mathrm{H}_{2}$ & 239 (4.62), $291(4.07)$ & 290 & $353\left(9 \times 10^{-2}\right)$ \\
\hline $2 a$ & $244(4.17)$ & - & $-^{c}$ \\
\hline $2 \mathbf{b}$ & $315(4.26)$ & 315 & 405 (n.d. $^{d}$ ) \\
\hline $2 c$ & 276 (4.50), 287 (4.49), 332 (4.55), 350sh (4.42), 365sh (4.23) & 332 & $411\left(6 \times 10^{-3}\right)$ \\
\hline 2d & 256 (5.35), 354sh (3.94), $372(4.14), 392(4.20)$ & 392 & $525\left(7 \times 10^{-3}\right)$ \\
\hline$\left[\operatorname{Ti}(\mathbf{1})_{2}(\mathbf{2 c})\right]$ & $244(5.08), 280 \operatorname{sh}(4.88), 293 \operatorname{sh}(4.81), 334(4.82), 380 \operatorname{sh}(4.72)$ & 380 & $477\left(<10^{-3}\right)$ \\
\hline$\left[\operatorname{Ti}(\mathbf{1})_{2}(\mathbf{2 d})\right]$ & $253(5.33), 365 \operatorname{sh}(4.13), 385 \operatorname{sh}(4.20), 433(4.32)$ & 365 & $490\left(<10^{-3}\right)$ \\
\hline
\end{tabular}

${ }^{a}$ Conditions: solutions in dichloromethane at room temperature (concentration range: absorption $=9-55 \mu \mathrm{M} ;$ emission $=1-3 \mu \mathrm{M}$ ); $\Phi=$ quantum yield; sh $=$ shoulder. ${ }^{b} \varepsilon$ in $\mathrm{M}^{-1} \mathrm{~cm}^{-1} .{ }^{c}$ Not photoluminescent. ${ }^{d}$ Not determined (very weak luminescence).

electronic delocalization. The spectrum of $2 \mathrm{c}$ exhibits several bands of similar intensities, ranging from 276 to $365 \mathrm{~nm}$; strikingly, the UV-vis spectrum of a reported bis(naphthylvinyl)substituted pyrimidine also exhibits signals at 276 and $332 \mathrm{~nm}$ with comparable absorption coefficients. ${ }^{22 b}$ Following the interpretation of Le Bozec et al. with regard to other related molecules, viz. tetrakis(arylvinyl)-substituted bipyrimidines, ${ }^{22 a}$ these absorptions can be assigned to intramolecular charge transfer (ICT) from the phenyl or naphthyl group towards the electron-deficient bipyrimidine nucleus. This statement is supported by the coplanarity of each aryl group with a vinyl bridge and with the pyrimidine cycle, which is observed on the X-ray structures shown in Fig. 1 (assuming that coordination to titanium does not affect the conformation of the ligand); this coplanarity allows a delocalization of the $\pi$ electrons. However, as far as $\left[\operatorname{Ti}(\mathbf{1})_{2}(\mathbf{2 b})\right]$ and $\left[\mathrm{Ti}(\mathbf{1})_{2}(\mathbf{2 d})\right]$ bear only two substituents instead of four, and as the aryl groups bear no donor atom, the transitions that we observe lie at a higher energy than the reported transition. ${ }^{2 a}$

Finally, the absorption spectrum of compound $2 \mathbf{d}$ contrasts with that of $2 \mathbf{b}$ and $2 \mathbf{c}$, with an intense blue-shifted band at $256 \mathrm{~nm}$ (probably assigned to a vinylpyrimidine-centered transition) and less intense bands at 354, 372 and $392 \mathrm{~nm}$. The pattern of the latter is reminiscent of the absorption spectrum of anthracene itself. ${ }^{37 a}$ Therefore, the spectrum of $\mathbf{2 d}$ suggests the absence of electronic connection with the anthracene moieties and the rest of the molecule. Again, this is in agreement with the conformation of this crystal structure of the titanium derivative $\left[\operatorname{Ti}(\mathbf{1})_{2}(\mathbf{2 d})\right]$ (Fig. 1) where the anthryl mean planes make an angle of $67.25^{\circ}$ with the vinyl planes.

The UV-vis spectra of the complexes $\left[\operatorname{Ti}(\mathbf{1})_{2}(\mathbf{2 a}-\mathbf{d})\right]$ display various intense bands $(4.13<\log \varepsilon<5.33)$ between 244 and $433 \mathrm{~nm}$ that can be reasonably assigned to ligand-centered $\left(\pi \rightarrow \pi^{*}\right)$ transitions. For complexes $\left[\operatorname{Ti}(\mathbf{1})_{2}(\mathbf{2 c})\right]$ and $\left[\operatorname{Ti}(\mathbf{1})_{2}(\mathbf{2 d})\right]$, the pattern of the free ligands $\mathbf{2 c}$ and $\mathbf{2 d}$ is roughly reproduced (Fig. 6). In addition, they exhibit a very broad and less intense band; this band is often obscured by the other transitions, but it is revealed by its tail in the visible region (roughly up to $520 \mathrm{~nm}$ ) and is responsible for the red or orange color of the solutions. In the case of complex $\left[\mathrm{Ti}(\mathbf{1})_{2}(\mathbf{2 a})\right]$, it is fairly detectable and is cen- tered at $c a .380 \mathrm{~nm}$. It can be assigned to an aryloxide-to-Ti LMCT transition, in agreement with the literature data. ${ }^{30 d, 38}$

The photoluminescence analyses were conducted at low concentrations in order to avoid self-absorption effects. Compound 1- $\mathrm{H}_{2}$ exhibits a strong luminescence at $353 \mathrm{~nm}$ with a quantum yield slightly lower than $10 \%$. In comparison, the light-induced emission properties of phenol-derived organic molecules related to compound $1-\mathrm{H}_{2}$ have been reported. ${ }^{39}$ Ligand 2a is not light-emissive in solution at RT, which is not surprising because $2,2^{\prime}$-bipyrimidine is not either; ${ }^{33 a}$ it is noteworthy that even the $\pi$-delocalized $4,4^{\prime}$ diphenyl-6,6'-dimethyl-2,2'-bipyrimidine ligand is not photoluminescent at room temperature. ${ }^{34 a} \mathbf{2 b}$ is only slightly emissive, and the corresponding titanium complexes $\left[\operatorname{Ti}(\mathbf{1})_{2}(\mathbf{2 a})\right]$ and $\left[\operatorname{Ti}(\mathbf{1})_{2}(\mathbf{2} \mathbf{b})\right]$ are not. Conversely, and as we expected, the 2-naphthyl and 9-anthryl-substituted ligands $2 \mathbf{c}$ and $2 \mathbf{d}$ are characterized by distinct emission signals respectively centered at 411 and $525 \mathrm{~nm}$ (Table 2 and Fig. 7). It is again interesting to compare the luminescence properties of these 4,4'-di(arylvinyl)-2,2'-bipyrimidines with those of related compounds: $4,6-$

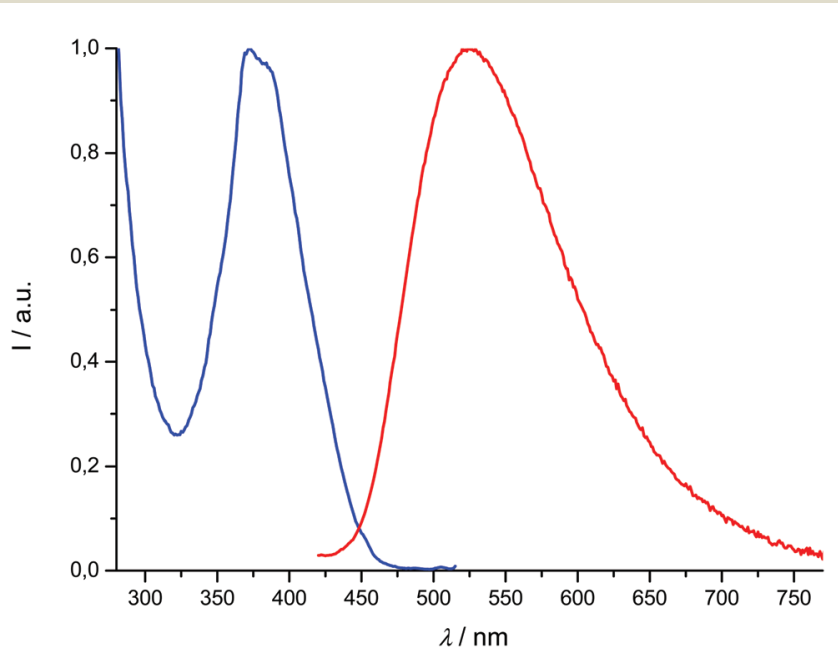

Fig. 7 Normalized excitation spectrum ( $\lambda_{\mathrm{em}}=525 \mathrm{~nm}$, blue) and emission spectrum ( $\lambda_{\text {exc }}=392 \mathrm{~nm}$, red) of compound $2 \mathbf{d}$ recorded at room temperature in $\mathrm{CH}_{2} \mathrm{Cl}_{2}$ (concentration: $1.91 \mu \mathrm{M}$ ). 
di(arylvinyl)pyrimidines, with aryl = 2-naphthyl or 9-anthryl, respectively, emitting at $\lambda_{\max }=424$ and $525 \mathrm{~nm} ;{ }^{22 b}$ or $4,4^{\prime}, 6,6^{\prime}$ tetra(arylvinyl)-2,2'-bipyrimidines (aryl $=N, N$-disubstituted aminophenyl), mentioned above, whose emissions are redshifted with respect to our data. ${ }^{22 a}$ With regard to quantum yields, $2 \mathrm{c}$ and $2 \mathrm{~d}$ are less emissive (0.6 and $0.7 \%$ ) than these species, especially the latter. We also note that under aerobic conditions, the quantum yield of anthracene itself reaches $21 \%$, whereas it is much lower with 4,6-di(anthrylvinyl)pyrimidine $(2 \%)$ or with $\mathbf{2 d}$; obviously the pyrimidine ring(s) partly quench the fluorescence of anthracene.

Of the four titanium complexes $\left[\operatorname{Ti}(\mathbf{1})_{2}(\mathbf{2 a}-\mathbf{d})\right]$, only $\left[\operatorname{Ti}(\mathbf{1})_{2}(\mathbf{2 c})\right]$ and $\left[\operatorname{Ti}(\mathbf{1})_{2}(\mathbf{2 d})\right]$ exhibit an emission, which is very weak, so that the quantum yields cannot be accurately determined; several excitation wavelengths were tested before we could detect a significant signal. Therefore, it appears that coordination to titanium(Iv) quenches the fluorescence of the ligands almost completely. The emission band of compound $\left[\operatorname{Ti}(\mathbf{1})_{2}(\mathbf{2 c})\right]$ undergoes a bathochromic shift with regard to $2 \mathrm{c}$ $\left(\Delta \lambda_{\max }=66 \mathrm{~nm}\right)$, while $\left[\operatorname{Ti}(\mathbf{1})_{2}(\mathbf{2 d})\right]$ is blue-shifted by $\Delta \lambda_{\max }=$ $35 \mathrm{~nm}$ with regard to $2 \mathbf{d}$. Overall, the lifetimes of the excited states are very low, within a 0.1-10 ns range (see the ESI $\dagger$ ). In addition, we checked that degassing a solution of $\left[\operatorname{Ti}(\mathbf{1})_{2}(\mathbf{2 d})\right]$ has no influence on the emission (which remains very weak), excluding thus any interaction with dioxygen. These data are in agreement with a fluorescence process (singlet excited states). The excitation spectra corresponding to the emission maxima reported in Table 2 were recorded and were usually in agreement with absorption spectra, with regard to the wavelength maxima observed in the spectra (compounds $1-\mathrm{H}_{2}, \mathbf{2 c}$, 2d, $\left.\left[\operatorname{Ti}(\mathbf{1})_{2}(\mathbf{2 c})\right]\right)$. The fit was not as good for compound $\left[\operatorname{Ti}(\mathbf{1})_{2}(\mathbf{2 d})\right]$, but many overlapping transitions were observed in the absorption spectrum; it is possible that some would be emissive and others would not.

\section{DFT calculations, frontier orbitals and discussion}

In addition to the experimental optical and emission properties evaluation, the frontier orbitals of the ligands and the complexes were computed using DFT calculations with the
B3LYP hybrid functional and cc-pVTZ basis functions. Calculations were performed with the GAUSSIAN09 Revision D01 software. ${ }^{40}$ Energies associated with these frontier orbitals are listed in Table 3. First of all, for the ligands an excellent match is found between the HOMO-LUMO gaps and the lower energy bands characterized by UV-visible absorption spectroscopy. The HOMO and LUMO representations obtained for the ligands $\mathbf{2 a - d}$ are shown in Fig. 8. For ligands $\mathbf{2 b}$ and $\mathbf{2 c}$, the HOMOs and the LUMOs are localized on one half of the molecules, indicating an electronic communication between the pyrimidine unit and the cyclic aromatic hydrocarbon part of the molecules. The situation is different for ligand $\mathbf{2 d}$, as the HOMO and to a lesser extent the LUMO are almost centred on the anthryl fragment. This is in good agreement with the 2d absorption spectrum in the region between $350 \mathrm{~nm}$ and $450 \mathrm{~nm}$, which resembles strongly the spectrum of anthracene (vide supra). This originated from a tilted arrangement of the anthryl units related to the pyrimidine units in $\mathbf{2 d}$, as shown in the $\left[\operatorname{Ti}(\mathbf{1})_{2}(\mathbf{2 d})\right]$ crystal structure (Fig. 1). Concerning frontier orbitals of the complexes shown in Fig. 9, similar tendencies are noticed between each complex. All HOMOs and HOMO-1 are localized on the substituted biphenolato ligand (HOMO-1 are given in the ESI $\dagger$ ). The LUMOs are all centred both on the metal and the nitrogen ligands. Indeed, the simple inspection of HOMOs, HOMO-1 and LUMO orbitals do not permit us to give clues about the origin of the emission properties modulations of $\mathbf{2 c}$ and $\mathbf{2 d}$ upon coordination to the titanium(rv) center. However, the examination of deeper orbitals for $\left[\operatorname{Ti}(\mathbf{1})_{2}(\mathbf{2 c})\right]$ and $\left[\operatorname{Ti}(\mathbf{1})_{2}(\mathbf{2 d})\right]$ is much more enlightening (the representations of the $\left[\mathrm{Ti}(\mathbf{1})_{2}(\mathbf{2 c})\right] \mathrm{HOMO}-6$ and $\mathrm{HOMO}-7$ are given in the ESI $\dagger$ ). For $\left[\operatorname{Ti}(\mathbf{1})_{2}(\mathbf{2 d})\right]$ as shown in Fig. 10, the anthryl fragments start to be involved for the HOMO-2 since the HOMO and the HOMO-1 are only centered on the biphenolato ligands. Furthermore, the energies associated with these orbitals are given in Table 4. Herein, an excellent match is found between the theoretical wavelength corresponding to the $\Delta E$ (LUMO-HOMO-2) and the $\lambda_{\max }$ determined experimentally in the visible region $\left(\lambda_{\text {(calcd) }}=438 \mathrm{~nm}, \lambda_{(\exp )}=\right.$ $433 \mathrm{~nm})$. Therefore, it can be reasonably proposed that upon

Table 3 LUMO+1, LUMO, HOMO, HOMO-1 energies for ligands $2 a-d$ and complexes $\left[T i(1)_{2}(2 a-d)\right]$

\begin{tabular}{|c|c|c|c|c|}
\hline & $\mathbf{2 a}(\mathrm{eV})$ & $2 \mathbf{b}(\mathrm{eV})$ & $2 \mathbf{c}(\mathrm{eV})$ & $2 \mathbf{d}(\mathrm{eV})$ \\
\hline LUMO & -1.599 & -2.202 & -2.319 & -2.327 \\
\hline HOMO-1 & -7.013 & -6.333 & -6.024 & -5.503 \\
\hline \multirow[t]{2}{*}{$\Delta(\text { LUMO-HOMO })^{a}$} & 4.992 & 4.025 & 3.662 & 3.138 \\
\hline & {$\left[\operatorname{Ti}(\mathbf{1})_{2}(\mathbf{2 a})\right](\mathrm{eV})$} & {$\left[\operatorname{Ti}(\mathbf{1})_{2}(\mathbf{2 b})\right](\mathrm{eV})$} & {$\left[\mathrm{Ti}(\mathbf{1})_{2}(\mathbf{2 c})\right](\mathrm{eV})$} & {$\left[\operatorname{Ti}(\mathbf{1})_{2}(\mathbf{2 d})\right](\mathrm{eV})$} \\
\hline LUMO & -2.695 & -2.922 & -2.978 & -2.903 \\
\hline HOMO & -5.552 & -5.439 & -5.400 & -5.487 \\
\hline HOMO-1 & -5.580 & -5.464 & -5.453 & -5.489 \\
\hline$\Delta($ LUMO-HOMO) & 2.857 & 2.517 & 2.422 & 2.584 \\
\hline
\end{tabular}

${ }^{a}$ Corresponding values of $\lambda: \mathbf{2 a}, 248 \mathrm{~nm} ; \mathbf{2 b}, 308 \mathrm{~nm} ; \mathbf{2 c}, 338 \mathrm{~nm} ; \mathbf{2 d}, 395 \mathrm{~nm}$. The experimental values of $\lambda$ are: $2 \mathbf{a}, 244 \mathrm{~nm}$; $2 \mathbf{b}, 315 \mathrm{~nm} ; 2 \mathbf{c}$, $332 \mathrm{~nm} ; 2 d, 392 \mathrm{~nm}$. 
HOMO

$2 a$

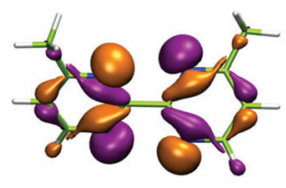

2b

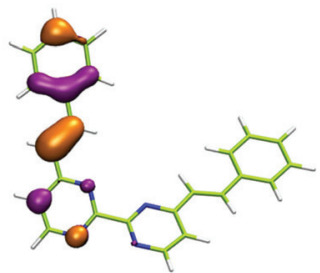

2c

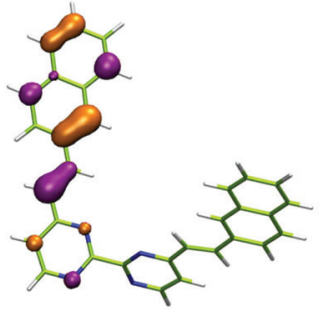

2d

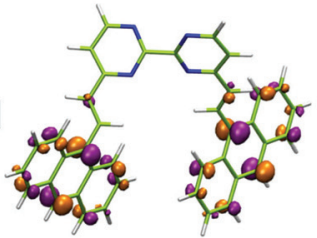

LUMO
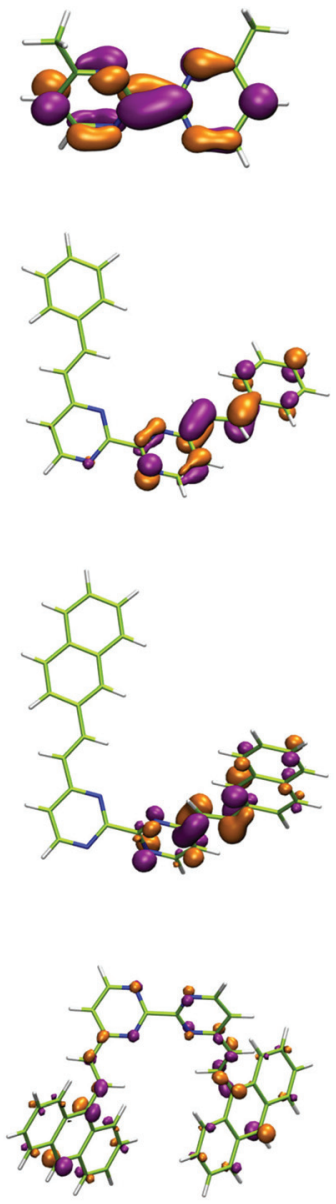

Fig. 8 HOMO and LUMO representations for ligands $2 a-d$.

excitation, an excited state is gained through the electronic promotion of an electron of a $\mathbf{2 d - c e n t e r e d ~ o c c u p i e d ~ o r b i t a l ~ t o ~}$ the $2 \mathrm{~d}$-centered LUMO orbital. As the 1-centered HOMO orbitals lie between the HOMOs and the LUMO involving $\mathbf{2 d}$, the fluorescence loss of $\mathbf{2 d}$ upon coordination is explained by an electron transfer of one electron of the 1-centered HOMO to the hole in the 2d-centered HOMOs. Transfer of the initially excited electron to the hole in the 1-centered HOMO follows this step. This intramolecular photoinduced electron transfer (PET) mechanism ${ }^{41}$ is shown in Fig. 11. An identical PET mechanism is proposed to explain the fluorescence quenching in $\left[\operatorname{Ti}(\mathbf{1})_{2}(\mathbf{2} \mathbf{c})\right]$. For $\left[\operatorname{Ti}(\mathbf{1})_{2}(2 \mathbf{c})\right]$, an excellent match is also found between the experimental $\lambda_{\max }(380 \mathrm{~nm})$ and the wavelength $\lambda_{\text {(calcd) }}=369 \mathrm{~nm}$ associated with the gap determined between the frontier orbitals centered on the naphthyl fragment (LUMO-HOMO-6).

\section{Biological properties}

As mentioned above, a promising issue for Ti(rv) complexes concerns some applications in biology and more particularly as antitumor agents. Therefore, the biological activity of the titanium-based compounds was tested on cell viability in the

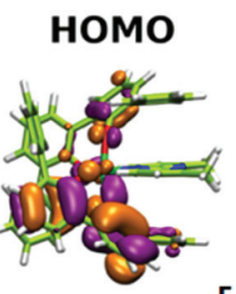

\section{$\left[\mathrm{Ti}(1)_{2}(2 \mathrm{a})\right]$}
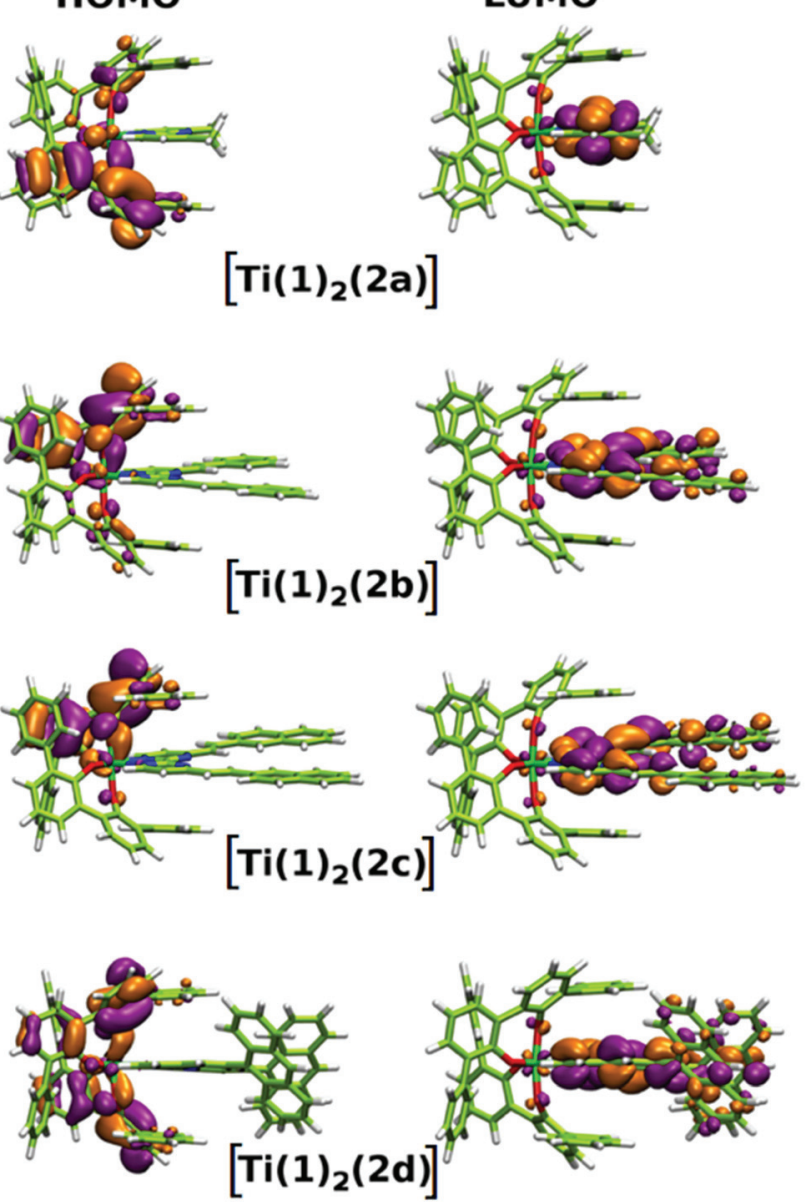

Fig. $9 \mathrm{HOMO}$ and LUMO representations for complexes $\left[\mathrm{Ti}(\mathbf{1})_{2}(2 \mathrm{a}-\mathrm{d})\right]$.

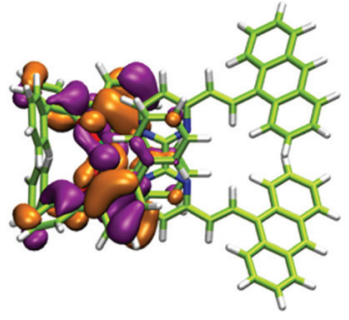

HOMO-1

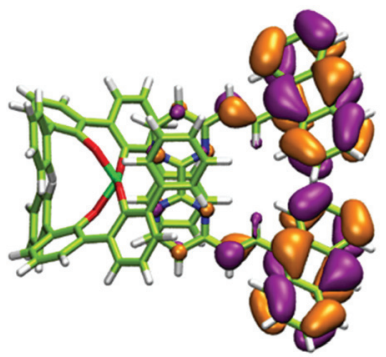

HOMO-3

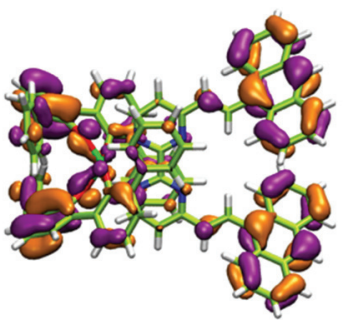

HOMO-2

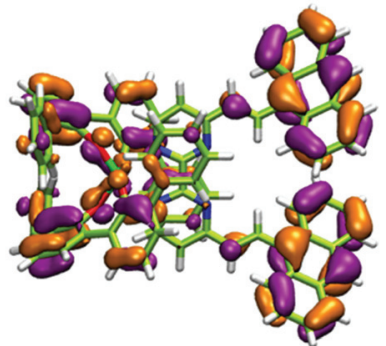

HOMO-4
Fig. 10 HOMO-1, HOMO-2, HOMO-3 and HOMO-4 representations of the $\left[\mathrm{Ti}(1)_{2}(2 \mathrm{~d})\right]$ complex. 
Table 4 Selected LUMO and HOMO energies for complexes [Ti(1) $\left.)_{2}(2 \mathrm{c})\right]$ and $\left[\mathrm{Ti}(1)_{2}(2 \mathrm{~d})\right]$. Values in bold correspond to the HOMOs centered on the anthryl fragments and the naphthyl fragments in $\left[\mathrm{Ti}(\mathbf{1})_{2}(\mathbf{2 d})\right]$ and $\left[\mathrm{Ti}(1)_{2}(2 \mathrm{c})\right]$ respectively

\begin{tabular}{lll}
\hline & {$\left[\operatorname{Ti}(\mathbf{1})_{2}(\mathbf{2 c})\right](\mathrm{eV})$} & {$\left[\operatorname{Ti}(\mathbf{1})_{2}(\mathbf{2 d})\right](\mathrm{eV})$} \\
\hline LUMO+1 & -2.684 & -2.722 \\
LUMO & -2.978 & -2.903 \\
HOMO & -5.400 & -5.487 \\
HOMO-1 & -5.453 & -5.489 \\
HOMO-2 & -5.465 & $-\mathbf{5 . 7 2 8}$ \\
HOMO-3 & -5.466 & $-\mathbf{5 . 7 3 7}$ \\
HOMO-4 & -5.887 & $-\mathbf{5 . 7 5 8}$ \\
HOMO-5 & -5.922 & \\
HOMO-6 & $\mathbf{- 6 . 3 4 1}$ & \\
HOMO-7 & $\mathbf{- 6 . 3 7 0}$ &
\end{tabular}

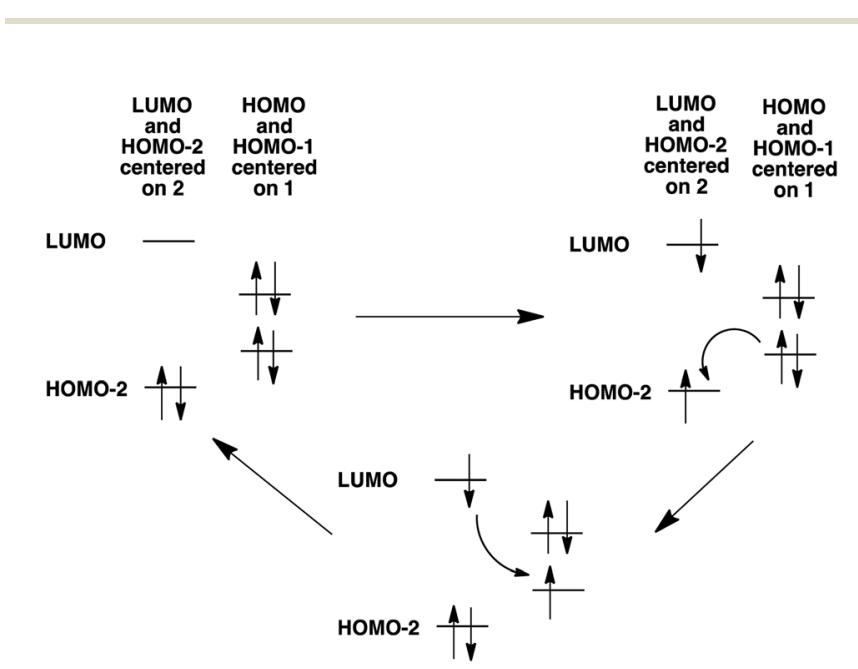

Fig. 11 Mechanism for PET explaining the luminescence quenching of $2 \mathrm{~d}$ in $\left[\mathrm{Ti}(\mathbf{1})_{2}(\mathbf{2 d})\right]$. A similar mechanism is proposed concerning the luminescence quenching of $2 \mathrm{c}$ in $\left[\mathrm{Ti}(1)_{2}(2 \mathrm{c})\right]$.

AGS gastric cancer cells. The cells were treated for 48 hours with increased concentrations of the drugs ranging from 1 to $200 \mu \mathrm{M}$ (Fig. 12). The compounds were first solubilized in DMSO at a concentration of $10 \mathrm{mM}$ for $\left[\mathrm{Ti}(\mathbf{1})_{2}(\mathbf{2 a})\right]$ and $2.5 \mathrm{mM}$ for $\left[\operatorname{Ti}(\mathbf{1})_{2}(\mathbf{2 b})\right],\left[\operatorname{Ti}(\mathbf{1})_{2}(\mathbf{2 c})\right]$ and $\left[\operatorname{Ti}(\mathbf{1})_{2}(\mathbf{2 d})\right]$ before a final dilution in the culture medium. The cell viability was measured using MTT assay. $\left[\operatorname{Ti}(\mathbf{1})_{2}(\mathbf{2 a})\right]$ showed a moderate reduction of AGS viability reaching the $\mathrm{IC}_{50}$ at about $200 \mu \mathrm{M}$. In contrast, $\left[\operatorname{Ti}(\mathbf{1})_{2}(\mathbf{2 b})\right],\left[\operatorname{Ti}(\mathbf{1})_{2}(\mathbf{2 c})\right]$ and $\left[\operatorname{Ti}(\mathbf{1})_{2}(\mathbf{2 d})\right]$ caused a marked diminution of cell viability already at $75 \mu \mathrm{M}$. Higher doses of $\left[\operatorname{Ti}(\mathbf{1})_{2}(\mathbf{2 b})\right],\left[\operatorname{Ti}(\mathbf{1})_{2}(\mathbf{2} \mathbf{c})\right]$ and $\left[\operatorname{Ti}(\mathbf{1})_{2}(\mathbf{2 d})\right]$ were not possible to test due to the poor solubility of these compounds in DMSO and the toxic effect of high doses of DMSO. The concentrations able to reduce by $50 \%$ the cell viability $\left(\mathrm{IC}_{50}\right)$ were determined using as maximal effect wells with no cells alive due to high cisplatin doses (Fig. 13) in order to compare the relative cytotoxicity of the various drugs. Systematically, the impact of DMSO alone was tested in parallel, and its lack of toxicity checked at the concentrations of the tests. Similar $\mathrm{IC}_{50}$ results were obtained when the drugs were incubated in a medium for 4 hours and before a fresh medium without drugs
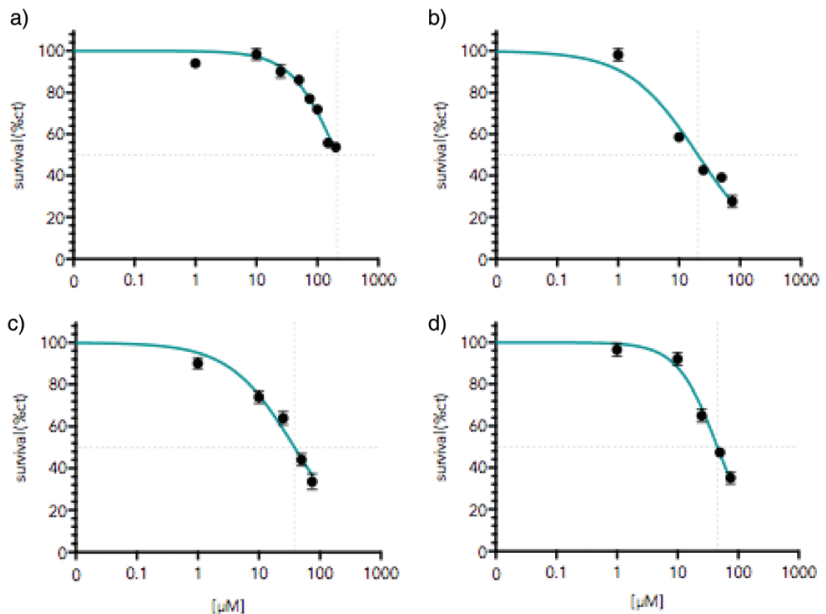

Fig. 12 Titanium complexes reduce AGS gastric cancer cells viability. AGS cells were treated with increasing concentration of the titanium complex ranging from $1 \mu \mathrm{M}$ to $200 \mu \mathrm{M}$ for 48 hours; (a) [Ti(1) $2(2 \mathrm{a})$ ], (b) $\left[\mathrm{Ti}(1)_{2}(2 \mathrm{~b})\right]$, (c) $\left[\mathrm{Ti}(1)_{2}(2 \mathrm{c})\right]$, (d) $\left[\mathrm{Ti}(1)_{2}(2 \mathrm{~d})\right]$. Cell viability was assessed by MTT assay. Graphs represent mean $(n=8)$ with standard deviation of one representative experiment $(n=3)$. ${ }^{*} p<0.01$ as calculated by a oneway ANOVA test followed by a Tukey post-test. Lines indicate $\mathrm{IC}_{50}$ calculated taking as maximal effect wells with cells completely dead due to the high dose of cisplatin. For each dose, the equivalent dose of DMSO without a titanium compound was tested to verify the lack of toxicity caused by DMSO.

\begin{tabular}{|c|c|}
\hline Name & $\mathrm{IC}_{50} \boldsymbol{\mu M}$ \\
\hline$\left[\mathrm{Ti}(1)_{2}(2 \mathrm{a})\right]$ & $274 \pm 56$ \\
\hline$\left[\mathrm{Ti}(1)_{2}(2 \mathrm{~b})\right]$ & $12 \pm 1.2$ \\
\hline$\left[\mathrm{Ti}(1)_{2}(2 \mathrm{c})\right]$ & $28 \pm 2.3$ \\
\hline$\left[\operatorname{Ti}(1)_{2}(2 d)\right]$ & $42 \pm 12$ \\
\hline $2 b$ & $6.2 \pm 1.2$ \\
\hline $2 c$ & $11.6 \pm 2.3$ \\
\hline $2 d$ & $88 \pm 32$ \\
\hline Cisplatin & $10 \pm 2$ \\
\hline
\end{tabular}

Fig. $13 I_{50}$ for $\left[\mathrm{Ti}(1)_{2}(2 a-d)\right]$ and ligands $2 b-d$ calculated as described in Fig. 12.

was replaced for the remaining 44 hours before MTT assay. These results indicate that the structure of the titanium complex has a direct impact on the biological activity of the compound.

To follow the localization of the compounds in cells, we incubated for 4 hours the compounds with AGS cells and we observed the fluorescence of the compounds under a fluorescent microscope (Fig. 14a). We compared the cells treated 


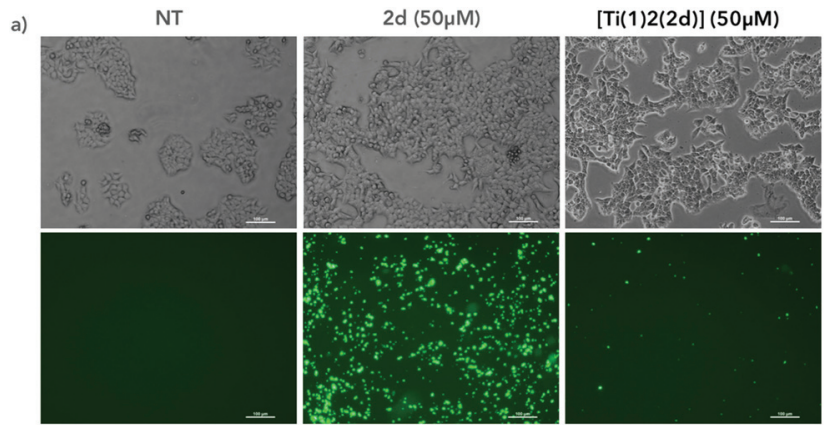

b)

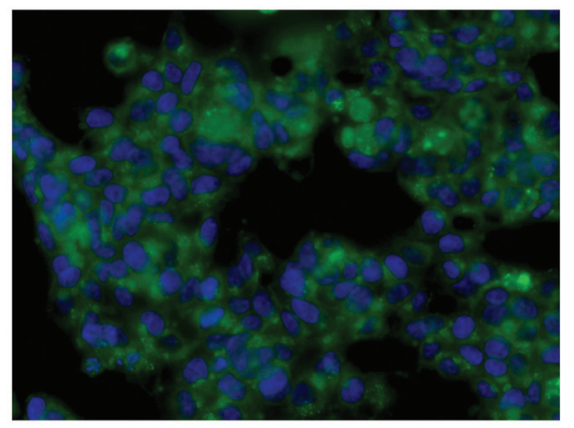

$[T i(1) 2(2 d)](50 \mu M)$

Fig. 14 AGS cells were treated with $\left[\mathrm{Ti}(1)_{2}(2 \mathrm{~d})\right]$ containing a fluorescent ligand or with the ligand alone (2d) at $50 \mu \mathrm{M}$ for 4 hours (a) or with DMSO (NT). Cells were then observed under a microscope in a bright field (a, top panels) or at excitation $433 \mathrm{~nm}$ and emission $532 \mathrm{~nm}$ and $461 \mathrm{~nm}$ (a, bottom panels and b). (b) Bottom panels show magnifications of cells treated with $\left[\mathrm{Ti}(\mathbf{1})_{2}(\mathbf{2 d})\right]$ (in green) and labelled with DAPI to visualize nuclei (in blue).

with the $\left[\operatorname{Ti}(\mathbf{1})_{2}(\mathbf{2 d})\right]$ versus the cells treated with the fluorescent ligand alone (2d). In both conditions, we observed fluorescent aggregates, reflecting the poor solubility of the compound in the medium. At a similar concentration $(50 \mu \mathrm{M})$, the overall fluorescence was reduced with the titanium complex compared to the ligand alone, which is in full accordance with the conclusions drawn from the fluorimetric assay. At a higher magnification, we observed the presence of fluorescence inside the cells and around the nucleus labeled with the fluorescent nucleus dye DAPI (Fig. 14b). However, at this stage, we are not able to conclude if the complex has crossed the cellular membrane and liberated the diimine ligand into the cells or if the free ligand has been generated in the extracellular medium before entering into the cells. Further investigations are planned to elucidate that point.

\section{Conclusions and perspectives}

We have reported herein the synthesis, using a well-established procedure, of a series of octahedral $\mathrm{TiO}_{4} \mathrm{~N}_{2}$-based complexes bearing substituted 2,2'-bipyrimidine ligands starting from $\left[\operatorname{Ti}(\mathbf{1})_{2}\left(\mathrm{HO}^{\mathrm{i}} \mathrm{Pr}\right)_{2}\right]$. Two of these complexes, i.e. $\left[\mathrm{Ti}(\mathbf{1})_{2}(\mathbf{2 c})\right]$ and $\left[\operatorname{Ti}(\mathbf{1})_{2}(2 \mathrm{~d})\right]$, incorporate fluorescent nitrogen ligands which contain naphthyl and anthryl fragments, respectively. We have demonstrated that the luminescent properties of $2 \mathbf{c}$ and $2 \mathbf{d}$ are strongly affected by their coordination to the $\operatorname{Ti}(\mathbf{1})_{2}$ unit, as a strong fluorescence loss is observed for the $\left[\operatorname{Ti}(\mathbf{1})_{2}(\mathbf{2 c})\right]$ and $\left[\mathrm{Ti}(\mathbf{1})_{2}(\mathbf{2 d})\right]$ complexes relative to the free nitrogen ligands. The explanation of the emission quenching has been provided by the examination of the HOMO and LUMO levels. We have also noticed a rather good hydrolytic stability for these Ti(Iv)-based species that is correlated to the size of the polyaromatic substituents decorating the nitrogen ligand backbone. Interestingly, this stability is affected by the addition of an acid. Additionally, preliminary biological studies were carried out. The toxicity of these compounds has been evaluated, highlighting that the complexes and the nitrogen ligands are moderately toxic. Also, we observed fluorescence inside the cells when they were treated with the complex $\left[\operatorname{Ti}(\mathbf{1})_{2}(\mathbf{2 d})\right]$. The longterm applications of the behaviour of this family of complexes in a medical or biological context are envisaged since $\mathrm{pH}^{-}$ responsive systems are highly attractive for developing novel drug delivery systems or analytical tools. ${ }^{42}$ However, before envisaging such applications, the solubility of these Ti(rv)based compounds in aqueous media must be significantly improved.

\section{Experimental part}

\section{General procedures}

Bruker Avance-300 and Avance-500 spectrometers were used for solution NMR spectroscopy analysis. Mass spectroscopy and elemental analyses were performed at the Service Commun d'Analyses, University of Strasbourg (France). The electrospray analyses were performed on Micro-TOF (Bruker) apparatus equipped with an electrospray (ES) source. The elemental analyses were performed on a Flash 2000 (Thermo Fisher Scientific) for $\mathrm{C}, \mathrm{H}$, and $\mathrm{N}$ elements. The analyzed mass peaks refer to the most intense peaks (unless mentioned otherwise in the discussion). 2-Chloro-4-phenyl-6 methyl-pyrimidine, triphenylphosphine, $\mathrm{NiCl}_{2} \cdot 6 \mathrm{H}_{2} \mathrm{O}$, zinc powder, and ${ }^{t} \mathrm{BuOK}$ were used as received from Alfa-Aesar or Sigma Aldrich. All solvents were dried before use with activated $3 \AA$ molecular sieves. Tetrahydrofuran (THF) was dried by distillation using sodium/benzophenone.

4,4'-Dimethyl-2,2'-bipyrimidine (2a). Under $\mathrm{N}_{2}$ protection, in a mixture of 2-chloro-4-phenyl-6 methyl-pyrimidine (2 g, $15.56 \mathrm{mmol}), \mathrm{NiCl}_{2} \cdot 6 \mathrm{H}_{2} \mathrm{O}(924 \mathrm{mg}, 3.89 \mathrm{mmol})$, triphenylphosphine (4.08 g, $15.56 \mathrm{mmol}$ ), and zinc powder (508 mg, $7.78 \mathrm{mmol}$ ) was added $50 \mathrm{~mL}$ of degassed DMF. The mixture was heated at $70^{\circ} \mathrm{C}$ overnight. The resulting dark red solution was poured into a solution of $2 \mathrm{M}$ aqueous ammonia $(100 \mathrm{~mL})$. The solution was extracted in the first place with diethyl ether to eliminate triphenylphosphine residues and then with $\mathrm{CH}_{2} \mathrm{Cl}_{2}$. The organic layer $\left(\mathrm{CH}_{2} \mathrm{Cl}_{2}\right)$ was combined and evaporated to dryness. The resulting yellow solid was purified by flash chromatography on a silica gel using $\mathrm{CH}_{2} \mathrm{Cl}_{2} /$ $\mathrm{MeOH}(97 / 3)$ as an eluent, which provided BpymMe as a yellow solid (704 mg, 68\% yield). ${ }^{1} \mathrm{H}$ NMR $\left(\mathrm{CDCl}_{3}, 500 \mathrm{MHz}\right): \delta(\mathrm{ppm})$ $8.82(\mathrm{~d}, J=4.5 \mathrm{~Hz}, 2 \mathrm{H}), 7.24(\mathrm{~d}, J=2.7 \mathrm{~Hz}, 2 \mathrm{H}), 2.69(\mathrm{~s}, 6 \mathrm{H})$; 
${ }^{13} \mathrm{C} \mathrm{NMR}\left(\mathrm{CDCl}_{3}, 125 \mathrm{MHz}\right): \delta(\mathrm{ppm})$ 168.6, 162.5, 157.6, 121.1, 24.7. $\mathrm{Mp}=117{ }^{\circ} \mathrm{C}$; Anal. Calcd for $\mathrm{C}_{10} \mathrm{H}_{10} \mathrm{~N}_{4}$ : C\% $64.50 \mathrm{~N} \%$ $30.09 \mathrm{H} \% 5.41$; found C\% 64.40, N\% 30.01, H\% 5.33. MS (ESI) $\mathrm{m} / \mathrm{z}$ calcd for $[2 \mathrm{a}+\mathrm{Na}]^{+}=209.0803$ found 209.0790 .

Preparation of bipyrimidine compounds - general procedure. Under $\mathrm{N}_{2}$ protection, 4,4'-dimethyl-2,2'-bipyrimidine (50 mg, $0.218 \mathrm{mmol}$ ) was dissolved in distilled THF $(20 \mathrm{~mL})$ in a bicol flask at $-78{ }^{\circ} \mathrm{C}$. ${ }^{t} \mathrm{BuOK}(90 \mathrm{mg}, 0.8 \mathrm{mmol}$ ) was slowly added, the solution turned brown after a few minutes. Then the aldehyde derivative ( 2.3 equiv.) was added in small portions. After $10 \mathrm{~min}$, the mixture was stored at room temperature for $1 \mathrm{~h}$. Then, $10 \mathrm{~mL}$ of water was added to the solution and the THF was evaporated. The precipitate was removed by filtration. The resulting solid was purified by flash chromatography using $\mathrm{CH}_{2} \mathrm{Cl}_{2} / \mathrm{MeOH}(97 / 3)$ as an eluent.

4,4'-Di((E)-styryl)-2,2'-bipyrimidine (2b). Yield $=58 \% .{ }^{1} \mathrm{H}$ NMR ( $\left.\mathrm{CD}_{2} \mathrm{Cl}_{2}, 500 \mathrm{MHz}\right): \delta(\mathrm{ppm}) 8.93\left(\mathrm{~d},{ }^{3} \mathrm{~J}=3.9 \mathrm{~Hz}, 2 \mathrm{H}\right), 8.02$ (d, $\left.{ }^{3} J=16.1 \mathrm{~Hz}, 2 \mathrm{H}\right), 7.70(\mathrm{~m}, 4 \mathrm{H}), 7.51\left(\mathrm{~d},{ }^{3} J=5 \mathrm{~Hz}, 2 \mathrm{H}\right)$, 7.45-7.37 (complex, 6H), 7.29 (d, $\left.{ }^{3} J=16.0 \mathrm{~Hz}, 2 \mathrm{H}\right) .{ }^{13} \mathrm{C}$ NMR $\left(\mathrm{CD}_{2} \mathrm{Cl}_{2}, 125 \mathrm{MHz}\right): \delta$ (ppm) 163.5, 162.8, 157.8, 137.9, 135.7, 129.6, 129.0, 127.8, 126.0, 118.0. $\mathrm{Mp}=214^{\circ} \mathrm{C}$. Anal. Calcd for $\mathrm{C}_{24} \mathrm{H}_{18} \mathrm{~N}_{4} \cdot 1 / 3 \mathrm{CH}_{2} \mathrm{Cl}_{2}$ : C\% 74.80, N\% 14.34, $\mathrm{H} \%$ 4.82; found $\mathrm{C} \%$ 75.47, N\% 13.42, $\mathrm{H} \%$ 4.97. MS (ESI) $m / z$ calcd for $[2 \mathrm{~d}+\mathrm{H}]^{+}$ $=363.1531$ found 363.1587 .

4,4'-Bis((E)-2-(naphthalen-2-yl)vinyl)-2,2'-bipyrimidine (2c). Yield $=55 \% .{ }^{1} \mathrm{H}$ NMR $\left(\mathrm{CDCl}_{3}, 500 \mathrm{MHz}\right): \delta(\mathrm{ppm}) 8.99\left(\mathrm{~d},{ }^{3} J=\right.$ $4.7 \mathrm{~Hz}, 2 \mathrm{H}), 8.12\left(\mathrm{~d},{ }^{3} J=16.5 \mathrm{~Hz}, 2 \mathrm{H}\right), 8.05(\mathrm{~s}, 2 \mathrm{H}), 7.88$ (m, 8H), $7.59\left(\mathrm{~d},{ }^{3} J=5.2 \mathrm{~Hz}, 2 \mathrm{H}\right), 7.51(\mathrm{~m}, 4 \mathrm{H}), 7.47\left(\mathrm{~d},{ }^{3} J=\right.$ $16.5 \mathrm{~Hz}, 2 \mathrm{H}) .{ }^{13} \mathrm{C} \mathrm{NMR}\left(\mathrm{CDCl}_{3}, 125 \mathrm{MHz}\right): \delta(\mathrm{ppm})$ 164.1, $163.0,158.3,138.2$, 134.0, 133.5, 133.2, 129.3, 128.8, 128.5, $127.8,127.0,126.7,126.6,123.6,117.6 . \mathrm{Mp}=227{ }^{\circ} \mathrm{C}$. Anal. Calcd for $\mathrm{C}_{32} \mathrm{H}_{22} \mathrm{~N}_{4} \cdot \mathrm{CH}_{2} \mathrm{Cl}_{2}$ : C\% $72.40 \mathrm{~N} \% 12.95 \mathrm{H} \%$ 4.42; found $\mathrm{C} \%$ 72.49, $\mathrm{N} \% 12.36, \mathrm{H} \%$ 4.90. MS (ESI) $\mathrm{m} / \mathrm{z}$ calcd for $[\text { BpymNapht }+\mathrm{Na}]^{+}=485.1742$ found 485.1699 .

4,4'-Bis((E)-2-(anthracen-9-yl)vinyl)-2,2'-bipyrimidine (2d). Yield $=54 \% .{ }^{1} \mathrm{H} \mathrm{NMR}\left(\mathrm{CDCl}_{3}, 500 \mathrm{MHz}\right): \delta(\mathrm{ppm}) 9.07\left(\mathrm{~d},{ }^{3} \mathrm{~J}=\right.$ $5.1 \mathrm{~Hz}, 2 \mathrm{H}), 8.94$ (d, $\left.{ }^{3} J=16.0 \mathrm{~Hz}, 2 \mathrm{H}\right), 8.44$ (s, 2H), 8.36 (dd, $\left.{ }^{3} J=7.0 \mathrm{~Hz},{ }^{4} J=1.7 \mathrm{~Hz}, 4 \mathrm{H}\right), 8.01\left(\mathrm{dd},{ }^{3} J=6.0 \mathrm{~Hz},{ }^{4} J=1.7 \mathrm{~Hz}\right.$, $4 \mathrm{H}), 7.64\left(\mathrm{~d},{ }^{3} J=5.1 \mathrm{~Hz}, 2 \mathrm{H}\right), 7.51(\mathrm{~m}, 8 \mathrm{H}), 7.23\left(\mathrm{~d},{ }^{3} J=\right.$ 16.0 Hz, 2H); ${ }^{13} \mathrm{C} \mathrm{NMR}\left(\mathrm{CDCl}_{3}, 125 \mathrm{MHz}\right): \delta(\mathrm{ppm})$ 163.5, $163.3,158.6,135.7,134.8,131.4$, 130.7, 129.6, 128.9, 127.9, 126.1, 125.7, 125.4, 118.2. $\mathrm{Mp}=239{ }^{\circ} \mathrm{C}$. Anal. Calcd for $\mathrm{C}_{40} \mathrm{H}_{26} \mathrm{~N}_{4} \cdot 9 / 5 \mathrm{CH}_{2} \mathrm{Cl}_{2}$ : C\% 70.16, N\% 7.83, $\mathrm{H} \%$ 4.17; found $\mathrm{C} \%$ 69.75, N\% 7.90, H\% 4.27. MS (ESI) $m / z$ calcd for $[2 \mathrm{~d}+\mathrm{Na}]^{+}=$ 585.2055 found 585.2100 .

\section{Preparation of titanium(Iv) complexes - general procedure}

Under $\mathrm{N}_{2}$ protection (glove bag), a counter solvent was allowed to slowly diffuse into a solution containing the bipyrimidine ligand (1 equiv.) and the cis-[Ti(1) $\left.)_{2}\left(\mathrm{HO}^{\mathrm{i}} \mathrm{Pr}\right)_{2}\right] \operatorname{complex}^{24}(10 \mathrm{mg})$ in a minimum amount of dry $\mathrm{CH}_{2} \mathrm{Cl}_{2} / \mathrm{CHCl}_{3}$ in a small vial. Crystals were isolated by filtration.

$\left[\operatorname{Ti}(\mathbf{1})_{2}(2 a)\right]$. Crystals were obtained from 1,2 dichloroethane/ n-pentane. $\mathrm{C}_{58} \mathrm{H}_{42} \mathrm{~N}_{4} \mathrm{O}_{4} \mathrm{Ti} ; T=173(2) \mathrm{K}$; orthorhombic; space group $P 2(1) 2(1) 2(1) ; a=11.8033(3) \AA, b=16.0200(4) \AA, c=$ 23.9080(6) ̊; $V=4520.7(2) \AA^{3} ; Z=4 ; D_{\text {calcd }}=1.332 \mathrm{~g} \mathrm{~cm}^{-3}$; reflections collected: 90 802; $R_{\text {int }}=0.0572 ; R_{1}(F)(I>2 \sigma(I))=$ $0.0402, \mathrm{w} R_{2}\left(F^{2}\right)$ (all data) $=0.0917 ; \operatorname{GOF}\left(F^{2}\right)=1.027$. CCDC number 1468167. Yield $=61 \% .{ }^{1} \mathrm{H} \mathrm{NMR}\left(\mathrm{CD}_{2} \mathrm{Cl}_{2}, 500 \mathrm{MHz}\right)$ : $\delta(\mathrm{ppm}) 8.33\left(\mathrm{~d},{ }^{3} J=5.4 \mathrm{~Hz}, 2 \mathrm{H}\right), 7.44\left(\mathrm{dd},{ }^{3} J=7.3 \mathrm{~Hz},{ }^{4} J=\right.$ $3.3 \mathrm{~Hz}, 4 \mathrm{H}), 7.29\left(\mathrm{td},{ }^{3} J=7.5 \mathrm{~Hz},{ }^{4} J=1.9 \mathrm{~Hz}, 4 \mathrm{H}\right), 7.13\left(\mathrm{dd},{ }^{3} J=\right.$ $\left.7.4 \mathrm{~Hz},{ }^{4} J=2.0 \mathrm{~Hz}, 2 \mathrm{H}\right), 7.09\left(\mathrm{t},{ }^{3} J=7.6 \mathrm{~Hz}, 2 \mathrm{H}\right), 7.04(\mathrm{~m}, 6 \mathrm{H})$, $6.81\left(\mathrm{dd},{ }^{3} \mathrm{~J}=8.4 \mathrm{~Hz},{ }^{4} \mathrm{~J}=1.5 \mathrm{~Hz}, 6 \mathrm{H}\right), 6.73(\mathrm{~m}, 10 \mathrm{H}), 6.66(\mathrm{t}$, $\left.{ }^{3} J=7.4 \mathrm{~Hz}, 2 \mathrm{H}\right), 3.76(\mathrm{~s}, 6 \mathrm{H}) .{ }^{13} \mathrm{C} \mathrm{NMR}\left(\mathrm{CD}_{2} \mathrm{Cl}_{2}, 125 \mathrm{MHz}\right)$ : $\delta(\mathrm{ppm}) 170.9,160.7,160.0,157.2,155.2$, 138.8, 138.4, 131.8, $131.4,129.8,129.7,129.6,129.3,129.1,129.0,128.7,128.0$, 127.5, 127.0, 126.0, 125.3, 122.1, 120.9, 119.7, 24.4. MS (ESI) $\mathrm{m} / \mathrm{z}$ calcd for $\left[\left[\mathrm{Ti}(\mathbf{1})_{2}(\mathbf{2 a})\right]+\mathrm{H}\right]^{+}=907.27$ found 907.28.

$\left[\operatorname{Ti}(1)_{2}(2 \mathbf{b})\right]$. Crystals were obtained from $\mathrm{CH}_{2} \mathrm{Cl}_{2} / n$-pentane. $\mathrm{C}_{72} \mathrm{H}_{50} \mathrm{~N}_{4} \mathrm{O}_{4} \mathrm{Ti}, T=173(2) \mathrm{K}$; monoclinic; space group $P 21 / n$; $a=13.5432(3) \AA, \quad b=14.0231(4) \AA, c=29.0361(8) \AA ; \beta=93.2494$ (14) $)^{\circ} V=5505.6(3) \AA^{3} ; Z=4 ; D_{\text {calcd }}=1.307 \mathrm{~g} \mathrm{~cm}^{-3}$; reflections collected: $65399 ; R_{\text {int }}=0.0763 ; R_{1}(F)(I>2 \sigma(I))=0.0606$, $\mathrm{w} R_{2}\left(F^{2}\right)$ (all data) $=0.1947 ; \operatorname{GOF}\left(F^{2}\right)=1.036$. CCDC number 1468801. Yield $=51 \% .{ }^{1} \mathrm{H}$ NMR $\left(\mathrm{CDCl}_{3}, 500 \mathrm{MHz}\right): \delta(\mathrm{ppm})$ $8.36\left(\mathrm{~d},{ }^{3} \mathrm{~J}=5.8 \mathrm{~Hz}, 2 \mathrm{H}\right), 7.81\left(\mathrm{~d},{ }^{3} J=16.1 \mathrm{~Hz}, 2 \mathrm{H}\right), 7.74\left(\mathrm{~d},{ }^{3} J=\right.$ $7.4 \mathrm{~Hz}, 4 \mathrm{H}), 7.49(\mathrm{~m}, 10 \mathrm{H}), 7.25(\mathrm{~m}, 4 \mathrm{H}), 7.14$ (dd, ${ }^{3} J=7.4 \mathrm{~Hz}$, $\left.{ }^{4} J=1.4 \mathrm{~Hz}, 2 \mathrm{H}\right), 7.02(\mathrm{~m}, 10 \mathrm{H}), 6.86(\mathrm{~m}, 6 \mathrm{H}) 6.07$ (m, 5H), 6.59 $(\mathrm{m}, 3 \mathrm{H}) .{ }^{13} \mathrm{C}$ NMR $\left(\mathrm{CDCl}_{3}, 125 \mathrm{MHz}\right): \delta(\mathrm{ppm})$ 165.3, 160.8, 160.2 , 157.7, 155.5, 140.6, 138.7, 138.6, 135.2, 131.5, 131.3, $130.7,130.4,129.9,129.6,129.4,129.3,129.2,129.0,128.8$, 128.2 , 127.7, 127.4, 126.9, 125.9, 125.5, 125.4, 121.9, 119.4, 116.8. MS (ESI) $\mathrm{m} / \mathrm{z}$ calcd for $\left[\left[\mathrm{Ti}(\mathbf{1})_{2}(\mathbf{2 b})\right]+\mathrm{H}\right]^{+}=1083.3312$ found 1083.3406 .

[Ti(1) 2 (2c)]. Crystals were obtained from $\mathrm{CHCl}_{3} / n$-pentane. $2\left(\mathrm{C}_{80} \mathrm{H}_{54} \mathrm{~N}_{4} \mathrm{O}_{4} \mathrm{Ti}\right), \mathrm{C}_{5} \mathrm{H}_{12} ; T=173(2) \mathrm{K}$; monoclinic; space group

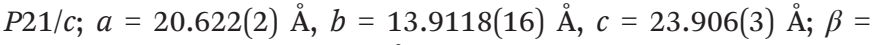
96.372(4) $)^{\circ} V=6816.0(14) \AA^{3} ; Z=2 ; D_{\text {calcd }}=1.188 \mathrm{~g} \mathrm{~cm}^{-3}$; reflections collected: $13151 ; R_{\text {int }}=0.1213 ; R_{1}(F)(I>2 \sigma(I))=$ $0.1288, \mathrm{w} R_{2}\left(F^{2}\right)$ (all data) $=0.3330 ; \operatorname{GOF}\left(F^{2}\right)=1.137$. CCDC number 1468168. Yield $=47 \% .{ }^{1} \mathrm{H} \mathrm{NMR}\left(\mathrm{CDCl}_{3}, 500 \mathrm{MHz}\right)$ : $\delta(\mathrm{ppm}) 8.39\left(\mathrm{~d},{ }^{3} J=5.2 \mathrm{~Hz}, 2 \mathrm{H}\right), 8.16(\mathrm{~s}, 2 \mathrm{H}), 7.95(\mathrm{~m}, 10 \mathrm{H})$, $7.58\left(\mathrm{dd},{ }^{3} J=5.2,{ }^{4} J=2.9 \mathrm{~Hz}, 4 \mathrm{H}\right), 7.48\left(\mathrm{~d},{ }^{3} J=7.5 \mathrm{~Hz}, 4 \mathrm{H}\right), 7.35$ (d, $\left.{ }^{3} J=15.6 \mathrm{~Hz}, 2 \mathrm{H}\right), 7.28(\mathrm{~m}, 4 \mathrm{H}), 7.16\left(\mathrm{dd},{ }^{3} J=8.1,{ }^{4} J=1.7\right.$ $\mathrm{Hz}, 2 \mathrm{H}), 7.03$ (m, 9H), $6.90(\mathrm{~m}, 6 \mathrm{H}), 6.73(\mathrm{~m}, 6 \mathrm{H}), 6.62(\mathrm{~m}, 3 \mathrm{H})$. ${ }^{13} \mathrm{C} \mathrm{NMR}\left(\mathrm{CDCl}_{3}, 125 \mathrm{MHz}\right): \delta(\mathrm{ppm}) 170.9,165.7,165.4,160.8$, $160.7,160.2$, 160.1, 157.8, 157.7, 157.5, 155.5, 155.4, 155.3, 140.8, 138.8, 138.7, 138.6, 138.5, 134.3, 133.5 (2 signals), 132.7, 132.6, 131.6, 131.5, 131.3, 131.1, 130.7, 130.2, 129.9, 129.7, 129.6, 129.5, 129.4 (2 signals), 129.3, 129.2, 129.0 (2 signals), 128.9 , 128.8, 128.7, 128.4, 128.3, 128.0, 127.9, 127.5, 127.4, 127.0, 126.9, 126.0, 125.9, 125.6, 125.5, 125.0, 123.6 (2 signals), $122.0,121.9,121.4,120.8,119.4,116.7,116.4$. MS (ESI) $m / z$ calcd for $\left[\left[\operatorname{Ti}(\mathbf{1})_{2}(2 \mathrm{c})\right]+\mathrm{Na}\right]^{+}=1205.3625$ found 1205.3411 .

$\left[\mathbf{T i}(\mathbf{1})_{2}(2 \mathrm{~d})\right]$. Crystals were obtained from $\mathrm{CHCl}_{3} / n$-pentane. $4\left(\mathrm{C}_{88} \mathrm{H}_{58} \mathrm{~N}_{4} \mathrm{O}_{4} \mathrm{Ti}\right), \mathrm{CHCl}_{3}, 4\left(\mathrm{H}_{2} \mathrm{O}\right) ; T=173(2) \mathrm{K}$; monoclinic; space group $P 2 / c ; a=21.6458(9) \AA, b=18.2186(10) \AA, c=$ 19.9733(11) А; $\beta=112.479(2)^{\circ} ; V=7278.1(6) \AA^{3} ; Z=1 ; D_{\text {calcd }}=$ $1.223 \mathrm{~g} \mathrm{~cm}^{-3}$; reflections collected: $19714 ; R_{\text {int }}=0.0869 ; R_{1}(F)$ $(I>2 \sigma(I))=0.0912, \mathrm{w} R_{2}\left(F^{2}\right)$ (all data) $=0.3117 ; \operatorname{GOF}\left(F^{2}\right)=1.051$. CCDC number 1468169. Yield $=41 \%$. ${ }^{1} \mathrm{H}$ NMR $\left(\mathrm{CDCl}_{3}\right.$, $500 \mathrm{MHz}): \delta$ (ppm) 9.14 (d, $\left.{ }^{3} J=15.8 \mathrm{~Hz}, 2 \mathrm{H}\right), 8.48(\mathrm{~m}, 4 \mathrm{H})$, 
$8.42\left(\mathrm{~d},{ }^{3} J=7.9 \mathrm{~Hz}, 4 \mathrm{H}\right), 8.03\left(\mathrm{dd},{ }^{3} J=7.9 \mathrm{~Hz},{ }^{4} J=1.8 \mathrm{~Hz}, 4 \mathrm{H}\right)$, 7.48 (m, 12H), 7.31 (m, 4H), 7.20 (dd, ${ }^{3} J=7.3 \mathrm{~Hz},{ }^{4} J=1.2 \mathrm{~Hz}$, 2H), $7.05(\mathrm{~m}, 14 \mathrm{H}), 6.86(\mathrm{~m}, 10 \mathrm{H}), 6.72\left(\mathrm{t},{ }^{3} \mathrm{~J}=7.3 \mathrm{~Hz}, 2 \mathrm{H}\right)$. Dept ${ }^{13} \mathrm{C} \mathrm{NMR}\left(\mathrm{CDCl}_{3}, 125 \mathrm{MHz}\right): \mathrm{CH} \delta(\mathrm{ppm})$ 156.1, 138.1, $132.7,131.8,131.4,129.9,129.7,129.6,129.2$, 129.0, 128.6, 127.5, 127.0, 126.6, 126.0, 125.5 (2 signals), 125.0, 122.0, 119.5, 118.0. MS (ESI) $\mathrm{m} / \mathrm{z}$ calcd for $\left[\left[\mathrm{Ti}(\mathbf{1})_{2}(\mathbf{2 d})\right]+\mathrm{H}\right]^{+}=1283.3938$ found 1283.4100 .

\section{Preparation of the NMR samples for hydrolytic stability assay without and with DCl}

The preparation of the samples was conducted under an argon atmosphere. Complexes $\left[\operatorname{Ti}(\mathbf{1})_{2}(\mathbf{2 a})\right],\left[\operatorname{Ti}(\mathbf{1})_{2}(\mathbf{2 b})\right],\left[\operatorname{Ti}(\mathbf{1})_{2}(\mathbf{2} \mathbf{c})\right]$ and $\left[\operatorname{Ti}(\mathbf{1})_{2}(\mathbf{2 d})\right]$ were dissolved in dry DMSO- $d_{6}$. Then, the resulting solutions were transferred into an NMR tube. To these solutions were added $\mathrm{D}_{2} \mathrm{O}(50 \mu \mathrm{l})$. The final concentrations were $6 \mathrm{mM}$. The NMR tubes were closed with a Teflon cap. The final solutions were analyzed using a $600 \mathrm{MHz}$ spectrometer.

For the experiments conducted with DCl, the final concentrations were also $6 \mathrm{mM}$. Complex $\left[\operatorname{Ti}(\mathbf{1})_{2}(\mathbf{2 a})\right]$ was dissolved in dry DMSO- $d_{6}$. To this solution was added $50 \mu \mathrm{l}$ of an aqueous $\left(\mathrm{D}_{2} \mathrm{O}\right)$ solution of DCl. The more acidic solution contains $2.5 \mu \mathrm{l}$ of DCl solution ( 38 wt $\%$ in $\left.\mathrm{D}_{2} \mathrm{O}\right)\left(3 \times 10^{-5} \mathrm{~mol}, 9\right.$ equivalents versus $\left.\left[\operatorname{Ti}(\mathbf{1})_{2}(\mathbf{2 a})\right]\right)$ whereas the second solution contains $0.5 \mu \mathrm{l}$ of DCl solution $\left(38 \mathrm{wt} \%\right.$ in $\left.\mathrm{D}_{2} \mathrm{O}\right)\left(6 \times 10^{-6} \mathrm{~mol}, 1.8\right.$ equivalent versus $\left.\left[\operatorname{Ti}(\mathbf{1})_{2}(\mathbf{2 a})\right]\right)$.

\section{Cell cultures}

Human AGS gastric cancer cells were obtained from ATCC. AGS cells were manipulated and cultured in DMEM with 10\% FCS (Dominique Dutcher ${ }^{\mathrm{TM}}$ ) and $1 \%$ penicillin + streptomycin (Sigma) at $37{ }^{\circ} \mathrm{C}$ under a $5 \% \mathrm{CO}_{2}$ atmosphere as previously described. ${ }^{43}$

\section{Cell survival}

5000 cells were seeded per well in 96-well microplates (Falcon Multiwell), 24 hours prior to any treatment. The complexes were applied for $48 \mathrm{~h}$ in fresh medium. MTT assay was performed as previously described by replacing the medium with a fresh medium supplemented with $5 \mathrm{mg} \mathrm{L}{ }^{-1}$ MTT (Sigma) for 1 h. $^{44}$ The cells were lysed in isopropanol with $0.04 \mathrm{~N} \mathrm{HCl}$. Measurements were performed at $550 \mathrm{~nm}$. $\mathrm{IC}_{50}$ were calculated using as maximal value wells with complete loss of cell survival due to the high dose of cisplatin $(50 \mu \mathrm{M})$.

\section{Microscopy}

The cells were grown on cover glasses in a growth medium and incubated for 4 hours with the complexes at various dilutions. The cells were then incubated with DAPI (Thermo Fisher) for 15 min. After incubation, the cells were observed directly under an epifluorescence microscope (Zeiss Apotome V2 axiozoom) at excitation $433 \mathrm{~nm}$ and emission $532 \mathrm{~nm}$ and $461 \mathrm{~nm}$ (DAPI).

\section{X-ray crystallography}

The X-ray diffraction data were collected on a Bruker Smart CCD diffractometer with Mo-K $\alpha$ radiation $(\lambda=0.71073 \AA)$. The structures were solved and refined using the Bruker SHELXTL Software Package using SHELXS-97 (Sheldrick, 2014) and refined by full matrix least-squares on $F^{2}$ using SHELXL-97 (Sheldrick, 2014) with anisotropic thermal parameters for all non-hydrogen atoms. ${ }^{45}$ The hydrogen atoms were introduced at calculated positions and not refined (riding model). For the structures of compounds $\left[\operatorname{Ti}(\mathbf{1})_{2}(\mathbf{2 c})\right]$ and $\left[\operatorname{Ti}(\mathbf{1})_{2}(\mathbf{2 d})\right]$, we used the squeeze command because the solvents could not be identified.

\section{Photophysical measurements}

The UV-visible absorption spectra were recorded using a Perkin Elmer Lambda 650S spectrometer at room temperature with a $1 \mathrm{~cm}$ path cell. The luminescence spectra were recorded at room temperature using a Fluorolog FL3-22 spectrofluorometer (Horiba Jobin Yvon) equipped with a TBX-04 or an R928 detector. All of the luminescence measurements were performed on optically dilute solutions with spectrophotometrygrade dichloromethane, with a maximum absorbance of 0.08 . For the luminescence steady-state measurements, the spectrometer was equipped with a $450 \mathrm{~W}$ xenon lamp excitation source and excitation and emission double-grating monochromators with bandpass set at $2 \mathrm{~nm}$ for the experiments. The spectra were corrected for the lamp, the monochromators, and the detector responses; blanks (solvent alone) were recorded and subtracted from the raw spectra, unless otherwise stated. The luminescence quantum yields were determined in spectrophotometry-grade dichloromethane solutions using either terphenyl in cyclohexane $\left(\Phi=0.93\right.$, for compound $\left.1-\mathrm{H}_{2}\right)$ or quinine sulfate in aerated $0.05 \mathrm{M} \mathrm{H}_{2} \mathrm{SO}_{4}(\Phi=0.55$, for the other compounds) as luminescence standards. ${ }^{37 b}$

\section{Conflict of interest}

The authors declare no competing financial interest.

\section{Acknowledgements}

We thank Martine Heinrich for technical assistance and helpful discussions, and Benoît Colasson for a critical reading of the manuscript. We are also thankful for the technical support of E. Martin. This project was supported by the Centre National pour la Recherche Scientifique (CNRS, France), ARC, Ligue contre le Cancer, European action COST CM1105 (C. G.), the Laboratory of Excellence (LABEX) "Chemistry of Complex Systems" (scholarship to G. K.) and IDEX grant (Strasbourg University).

\section{References}

1 (a) R. Visbal and M. C. Gimeno, Chem. Soc. Rev., 2014, 43, 3551-3574; (b) V. W.-W. Yam and K. M.-C. Wong, Chem. 
Commun., 2011, 47, 11579-11592; (c) Y. Chi and P.-T. Chou, Chem. Soc. Rev., 2007, 36, 1421-1431.

2 (a) D.-L. Ma, V. P.-Y. Ma, D. S.-H. Chan, K.-H. Leung, H.-Z. He and C.-H. Leung, Coord. Chem. Rev., 2012, 256, 3087-3113; (b) X. He and V. W.-W. Yam, Coord. Chem. Rev., 2011, 255, 2111-2123; (c) B. A. DeGraff and J. N. Demas, Coord. Chem. Rev., 2001, 211, 317-351.

3 E. Baggaley, J. A. Weinstein and J. A. G. Williams, Coord. Chem. Rev., 2012, 256, 1762-1785.

4 (a) Y. Chi and P.-T. Chou, Chem. Soc. Rev., 2010, 39, 638655; (b) J. A. G. Williams, S. Develay, D. L. Rochester and L. Murphy, Coord. Chem. Rev., 2008, 252, 2596-2611.

5 S. I. Pascu, P. A. Waghorn, T. D. Conry, B. Lin, H. M. Betts, J. R. Dilworth, R. B. Sim, G. C. Churchill, F. I. Aigbirhio and J. E. Warren, Dalton Trans., 2008, 2107-2110.

6 S. I. Pascu, P. A. Waghorn, T. D. Conry, H. M. Betts, J. R. Dilworth, G. C. Churchill, T. Pokrovska, M. Christlieb, F. I. Aigbirhio and J. E. Warren, Dalton Trans., 2007, 49884997.

7 E. E. Langdon-Jones, D. Lloyd, A. J. Hayes, S. D. Wainwright, H. J. Mottram, S. J. Coles, P. N. Horton and S. J. A. Pope, Inorg. Chem., 2015, 54, 6606-6615.

8 S. W. Botchway, M. Charnley, J. W. Haycock, A. W. Parker, D. L. Rochester, J. A. Weinstein and J. A. Williams, Proc. Natl. Acad. Sci. U. S. A., 2008, 105, 16071-16076.

9 (a) V. Fernández-Moreira, F. L. Thorp-Greenwood and M. P. Coogan, Chem. Commun., 2010, 46, 186-202; (b) M. Klajner, C. Licona, L. Fetzer, P. Hebraud, G. Mellitzer, M. Pfeffer, S. Harlepp and C. Gaiddon, Inorg. Chem., 2014, 53, 5150-5158.

10 (a) D. J. Ramón and M. Yus, Chem. Rev., 2006, 106, 21262208; (b) R. O. Duthaler and A. Hafner, Chem. Rev., 1992, 92, 807-832.

11 S. A. Ryken and L. L. Schafer, Acc. Chem. Res., 2015, 48, 2576-2586.

12 (a) E. Le Roux, Coord. Chem. Rev., 2016, 306, 65-85; (b) V. C. Gibson and S. K. Spitzmesser, Chem. Rev., 2003, 103, 283-315; (c) L. Resconi, L. Cavallo, A. Fait and F. Piemontesi, Chem. Rev., 2000, 100, 1253-1345; (d) L. Azor, C. Bailly, L. Brelot, M. Henry, P. Mobian and S. Dagorne, Inorg. Chem., 2012, 51, 10876-10883.

13 U. Schubert, J. Mater. Chem., 2005, 15, 3701-3715.

14 (a) M. Albrecht, I. Janser, S. Kamptmann, P. Weis, B. Wibbeling and R. Fröhlich, Dalton Trans., 2004, 37-43; (b) M. Albrecht, I. Janser, A. Lützen, M. Hapke, R. Fröhlich and P. Weis, Chem. - Eur. J., 2005, 11, 5742-5748; (c) M. Scherer, D. L. Caulder, D. W. Johnson and K. N. Raymond, Angew. Chem., 1999, 111, 1689-1694, (Angew. Chem., Int. Ed., 1999, 38, 1587-1592); (d) M. Albrecht, H. Röttele and P. Burger, Chem. - Eur. J., 1996, 2, 1264-1268; (e) M. Albrecht, S. Kamtmann and R. Fröhlich, Polyhedron, 2003, 22, 643-647; (f) M. Albrecht, M. Schneider and R. Fröhlich, New J. Chem., 1998, 22, 753754; (g) M. Albrecht and S. Kotila, Angew. Chem., 1996, 108, 1299-1300, (Angew. Chem., Int. Ed. Engl., 1996, 35, 12081210); (h) Y. Sakata, S. Hiraoka and M. Shionoya, Chem. -
Eur. J., 2010, 16, 3318-3325; (i) C. Diebold, P. Mobian, C. Huguenard, L. Allouche and M. Henry, Inorg. Chem., 2010, 49, 6369-6371; (j) D. M. Weekes, C. Diebold, P. Mobian, C. Huguenard, L. Allouche and M. Henry, Chem. - Eur. J., 2014, 20, 5092-5101.

15 P. Mobian, N. Baradel, N. Kyritsakas, G. Khalil and M. Henry, Chem. - Eur. J., 2015, 21, 2435-2441.

16 C. W. Schwietert and J. P. McCue, Coord. Chem. Rev., 1999, 184, 67-89.

17 (a) K. M. Buettner and A. M. Valentine, Chem. Rev., 2011, 112, 1863-1881; (b) T. B. Parks, Y. M. Cruz and A. D. Tinoco, Inorg. Chem., 2014, 53, 1743-1749.

18 (a) For a review discussing the search of alternatives for administering Ti(Iv)-based metallo-drugs, see: W. A. Wani, S. Prashar, S. Shreaz and S. Gómez-Ruis, Coord. Chem. Rev., 2016, 312, 67-98. For general reviews on Ti(Iv)-based metallo-drugs, see: (b) K. Strohfeldta and M. Tackeb, Chem. Soc. Rev., 2008, 37, 1174-1187; (c) F. Caruso and M. Rossi, Mini-Rev. Med. Chem., 2004, 4, 49-60; (d) E. Meléndez, Crit. Rev. Oncol. Hematol., 2002, 42, 309-315.

19 (a) H. Glasner and E. Y. Tshuva, Inorg. Chem. Commun., 2015, 53, 31-33; (b) M. Grützke, T. Zhao, T. A. Immel and T. Huhn, Inorg. Chem., 2015, 54, 6697-6706; (c) H. Glasner, S. Meker and E. Y. Tshuva, J. Organomet. Chem., 2015, 788, 33-35; (d) T. Zhao, M. Grützke, K. H. Götz, T. Druzhenko and T. Huhn, Dalton Trans., 2015, 44, 16475-16485; (e) M. Lin, Y. Cao, H. Pei, Y. Chen, J. Wu, Y. Li and W. Liu, RSC Adv., 2014, 4, 9255-9260; (f) T. B. Parks, Y. M. Cruz and A. D. Tinoco, Inorg. Chem., 2014, 53, 1743-1749; (g) S. Barroso, A. M. Coelho, S. Gómez-Ruiz, M. J. Calhorda, Ž. Žižak, G. N. Kaluđerović and A. M. Martins, Dalton Trans., 2014, 43, 17422-17433; (h) R. Hernández, J. Méndez, J. Lamboy, M. Torres, F. R. Román and E. Meléndez, Toxicol. in Vitro, 2010, 24, 178-183; (i) A. D. Tinoco, H. R. Thomas, C. D. Incarvito, A. Saghatelian and A. M. Valentine, Proc. Natl. Acad. Sci. U. S. A., 2012, 109, 5016-5021; (j) E. Y. Tshuva and J. A. Ashenhurst, Eur. J. Inorg. Chem., 2009, 22032218.

20 For rare reports of luminescent titanium(Iv)-based complexes, see: B. P. Baranwal, A. K. Singh and A. Varna, Spectrochim. Acta, Part A, 2011, 125-129.

21 D. M. Weekes, N. Baradel, N. Kyritsakas, P. Mobian and M. Henry, Eur. J. Inorg. Chem., 2012, 34, 5701-5713.

22 (a) H. Akdas-Kilig, T. Roisnel, I. Ledoux and H. Le Bozec, New J. Chem., 2009, 33, 1470-1473; (b) S. Achelle, I. Nouira, B. Pfaffinger, Y. Ramondenc, N. Plé and J. RodríguezLópez, J. Org. Chem., 2009, 74, 3711-3717.

23 (a) J. B. Birks, Photophysics of Aromatic Molecules, WileyInterscience, London, 1970; (b) H. Park, J. Lee, I. Kang, H. Y. Chu, J. I. Lee, S. K. Kwon and Y. H. Kim, J. Mater. Chem., 2012, 22, 2695-2700; (c) P. Rajamalli and E. Prasad, Org. Lett., 2011, 13, 3714-3717; (d) H. Huang, Q. Fu, S. Zhuang, Y. Liu, L. Wang, J. Chen, D. Ma and C. Yang, J. Phys. Chem. C, 2011, 115, 4872-4878; (e) Y. Y. Lyu, J. Kwak, O. Kwon, S. H. Lee, D. Kim, C. Lee and K. Char, 
Adv. Mater., 2008, 20, 2720-2729; (f) H. Ihmels, A. Meiswinkel, C. J. Mohrschladt, D. Otto, M. Waidelich, M. Towler, R. White, M. Albrecht and A. Schnurpfeil, J. Org. Chem., 2005, 70, 3929-3938.

24 C. Diebold, P. Mobian, C. Huguenard, L. Allouche and M. Henry, Dalton Trans., 2009, 10178-10180.

25 (a) F. Caruso and M. Rossi, Mini-Rev. Med. Chem., 2004, 4, 49-60; (b) E. Melendez, Crit. Rev. Oncol. Hemat., 2002, 42, 309-315; (c) J. H. Toney and T. J. Marks, J. Am. Chem. Soc., 1985, 107, 947-953; (d) A. Tzubery and E. Tshuva, Inorg. Chem., 2012, 51, 1796-1804; (e) D. Peri, S. Meker, C. M. Manna and E. Y. Tshuva, Inorg. Chem., 2011, 50, 1030-1038; $(f)$ E. Y. Tshuva and D. Peri, Coord. Chem. Rev., 2008, 253, 2098-2115.

26 D. Peri, S. Meker, M. Shavit and E. Y. Thuva, Chem. - Eur. J., 2009, 15, 2403-2415.

27 These volumes are estimated according to A. Gavezotti, J. Am. Chem. Soc., 1983, 105, 5220-5225. van der Waals radii used: $H=1.2 \AA, C=1.7 \AA, N=1.55 \AA$ (see A. Bondi, J. Phys. Chem., 1964, 68, 441-451).

28 (a) M. Henry, in Encyclopedia of Nanoscience and Nanotechnology, ed. H. S. Nalwa, American Scientific Publishers, 2011, vol. 14, pp. 1-43; (b) M. Henry, in Advances in Quantum Chemical Bonding Structures, ed. M. V. Putz, Transworld Research Network, Kerala, India, 2009, pp. 153-211; (c) M. Henry, ChemPhysChem, 2002, 3, 561-569; (d) M. Henry, ChemPhysChem, 2002, 3, 607-616.

29 A. Erdoğmuş, M. Durmuş, A. L. Uur, O. Avciata, U. Avciata and T. Nyokong, Synth. Met., 2010, 160, 1868-1876.

30 (a) V. W.-W. Yam, G.-Z. Qi and K.-K. Cheung, J. Chem. Soc., Dalton Trans., 1998, 1819-1823; (b) G. V. Loukova, W. Huhn, V. P. Vasiliev and V. A. Smirnov, J. Phys. Chem. A, 2007, 111, 4117-4121; (c) V. E. Pritchard, F. L. ThorpGreenwood, R. G. Balasingham, C. F. Williams, B. M. Kariuki, J. A. Platts, A. J. Hallett and M. P. Coogan, Organometallics, 2013, 32, 3566-3569; (d) C. Romain, S. Choua, J.-P. Collin, M. Heinrich, C. Bailly, L. KarmazinBrelot, S. Bellemin-Laponnaz and S. Dagorne, Inorg. Chem., 2014, 53, 7371-7376.

31 (a) J. W. Kenney, D. R. Boone, D. R. Striplin, Y.-H. Chen and K. B. Hamar, Organometallics, 1993, 12, 3671-3676; (b) G. V. Loukova and V. A. Smirnov, Chem. Phys. Lett., 2000, 329, 437-442; (c) A. Vogler and H. Kunkely, Top. Curr. Chem., 2001, 213, 143-182; (d) E. L. Patrick, C. J. Ray, G. D. Meyer, T. P. Ortiz, J. A. Marshall, J. A. Brozik, M. A. Summers and J. W. Kenney, J. Am. Chem. Soc., 2003, 125, 5461-5470.

32 (a) K.-T. Wong, T. S. Hung, Y. Lin, C.-C. Wu, G.-H. Lee, S.-M. Peng, C. H. Chou and Y. O. Su, Org. Lett., 2002, 4, 513-516; (b) K. Itami, D. Yamazaki and J. Yoshida, J. Am. Chem. Soc., 2004, 126, 15396-15397; (c) S. Achelle, Y. Ramondenc, G. Dupas and N. Plé, Tetrahedron, 2008, 64, 2783-2791; (d) S. Achelle, I. Nouira, B. Pfaffinger, Y. Ramondenc, G. Dupas, N. Plé and J. Rodríguez-López, J. Org. Chem., 2009, 74, 3711-3717; (e) E. V. Verbitskiy, E. M. Cheprakova, J. O. Subbotina, A. V. Schepochkin,
P. A. Slepukhin, G. L. Rusinov, V. N. Charushin, O. N. Chupakhin, N. I. Makarova, A. V. Metelitsa and V. I. Minkin, Dyes Pigm., 2014, 100, 201-214; (f) S. Achelle, S. Kahlal, A. Barsella, J.-Y. Saillard, X. Che, J. Vallet, F. Bureš, B. Caro and F. Robin-le Guen, Dyes Pigm., 2015, 113, 562-570.

33 (a) H. Jang, C.-H. Shin, B.-J. Jung, D. Kim, H.-K. Shim and Y. Do, Eur. J. Inorg. Chem., 2006, 718-725; (b) S. Swavey, J. A. Krause, D. Collins, D. D'Cunha and A. Fratini, Polyhedron, 2008, 27, 1061-1069; (c) T. Lazarides, H. Adams, D. Sykes, S. Faulkner, G. Calogero and M. D. Ward, Dalton Trans., 2008, 691-698.

34 (a) Q.-D. Liu, R. Wang and S. Wang, Dalton Trans., 2004, 2073-2079; (b) H. Akdas-Kilig, T. Roisnel, I. Ledoux and H. Le Bozec, New J. Chem., 2009, 33, 1470-1473; (c) P. Savel, H. Akdas-Kilig, J.-P. Malval, A. Spangenberg, T. Roisnel and J.-L. Fillaut, J. Mater. Chem. C, 2014, 2, 295-305; (d) H. Akdas-Kilig, M. Godfroy, J.-L. Fillaut, B. Donnio, B. Heinrich, P. Kędziora, J.-P. Malval, A. Spangenberg, S. van Cleuvenbergen, K. Clays and F. Camerel, J. Phys. Chem. C, 2015, 2, 3697-3710.

35 M. Sarakha, M. Bolte and H. D. Burrows, J. Photochem. Photobiol., A, 1997, 107, 101-106.

36 V. M. Mukkala, C. Sund, M. Kwiatkowski, P. Pasanen, M. Högberg, J. Kankare and H. Takalo, Helv. Chim. Acta, 1992, 75, 1621-1632.

37 (a) M. Montalti, A. Credi, L. Prodi and M. T. Gandolfi, Handbook of Photochemistry, Taylor \& Francis, London, 2006, p. 570; (b) M. Montalti, A. Credi, L. Prodi and M. T. Gandolfi, Handbook of Photochemistry, Taylor \& Francis, London, 2006, p. 574.

38 D. Lionetti, A. J. Medvecz, V. Ugrinova, M. Quiroz-Guzman, B. C. Boll and S. N. Brown, Inorg. Chem., 2010, 49, 46874697.

39 (a) S. K. Nayaki and M. Swaminathan, J. Indian Chem. Soc., 2000, 77, 376-379; (b) Y. Kitayama, T. Amako, N. Suzuki, M. Fujiki and Y. Imai, Org. Biomol. Chem., 2014, 12, 43424346; (c) I. Yamaguchi, K. Sato and M. Okuno, J. Phys. Org. Chem., 2014, 27, 622-627.

40 M. J. Frisch, G. W. Trucks, H. B. Schlegel, G. E. Scuseria, M. A. Robb, J. R. Cheeseman, G. Scalmani, V. Barone, B. Mennucci, G. A. Petersson, H. Nakatsuji, M. Caricato, X. Li, H. P. Hratchian, A. F. Izmaylov, J. Bloino, G. Zheng, J. L. Sonnenberg, M. Hada, M. Ehara, K. Toyota, R. Fukuda, J. Hasegawa, M. Ishida, T. Nakajima, Y. Honda, O. Kitao, H. Nakai, T. Vreven Jr., J. A. Montgomery, J. E. Peralta, F. Ogliaro, M. Bearpark, J. J. Heyd, E. Brothers, K. N. Kudin, V. N. Staroverov, R. Kobayashi, J. Normand, K. Raghavachari, A. Rendell, J. C. Burant, S. S. Iyengar, J. Tomasi, M. Cossi, N. Rega, J. M. Millam, M. Klene, J. E. Knox, J. B. Cross, V. Bakken, C. Adamo, J. Jaramillo, R. Gomperts, R. E. Stratmann, O. Yazyev, A. J. Austin, R. Cammi, C. Pomelli, J. W. Ochterski, R. L. Martin, K. Morokuma, V. G. Zakrzewski, G. A. Voth, P. Salvador, J. J. Dannenberg, S. Dapprich, A. D. Daniels, Ö. Farkas, J. B. Foresman, J. V. Ortiz, J. Cioslowski and D. J. Fox, 
Gaussian 09, Revision D.01, Gaussian, Inc., Wallingford CT, 2009.

41 (a) J. Yoon and A. W. Czarnik, Bioorg. Med. Chem., 1993, 1, 267-271; (b) J. S. Kim and D. T. Quang, Chem. Rev., 2007, 107, 3780-3799.

42 (a) S. Park, E. Kim, W. Y. Kim, C. Kang and J. S. Kim, Chem. Commun., 2012, 51, 9343-9345; (b) A. V. Saura, M. J. Marin, M. I. Burguete, D. A. Russell, F. Galindo and S. V. Luis, Org. Biomol. Chem., 2015, 13, 7736-7749; (c) J. Hu, W. Zhao,
M. Sun, X. Liu and W. Gao, Chem. Commun., 2015, 1-4.

43 F. Sohm, C. Gaiddon, M. Antoine, A. L. Boutillier and J. P. Loeffler, Oncogene, 1999, 18, 2762-2769.

44 C. Gaiddon, M. de Tapia and J. P. Loeffler, Mol. Endocrinol., 1999, 13, 742-751.

45 (a) G. M. Sheldrick, Acta Crystallogr., Sect. A: Fundam. Crystallogr., 2008, 64, 112-122; (b) G. M. Sheldrick, Acta Crystallogr., Sect. C: Cryst. Struct. Commun., 2015, 71, 3-8. 